\title{
Genetic-linked Inattentiveness Protects Individuals from Internet Overuse: A Genetic Study of Internet Overuse Evaluating Hypotheses Based on Addiction, Inattention, Novelty-seeking and Harm-avoidance
}

\author{
Cheng Sun and Rita Spathis \\ Binghamton University, \\ Binghamton, NY, USA \\ csun@binghamton.edu; \\ rspathis@gmail.com \\ Chim W. Chan \\ Karolinska Institutet, \\ Stockholm, Sweden \\ chim.chan@ki.se
}

Krithivasan Sankaranarayanan University of Oklahoma, Norman, OK, USA

ksankar@ou.edu

\author{
J. Koji Lum \\ Binghamton University, \\ Binghamton, NY, USA \\ klum@binghamton.edu
}

\begin{abstract}
Material published as part of this publication, either on-line or in print, is copyrighted by the Informing Science Institute. Permission to make digital or paper copy of part or all of these works for personal or classroom use is granted without fee provided that the copies are not made or distributed for profit or commercial advantage AND that copies 1) bear this notice in full and 2) give the full citation on the first page. It is permissible to abstract these works so long as credit is given. To copy in all other cases or to republish or to post on a server or to redistribute to lists requires specific permission and payment of a fee. Contact Publisher@InformingScience.org to request redistribution permission.
\end{abstract}

The all-pervasive Internet has created serious problems, such as Internet overuse, which has triggered considerable debate over its relationship with addiction. To further explore its genetic susceptibilities and alternative explanations for Internet overuse, we proposed and evaluated four hypotheses, each based on existing knowledge of the biological bases of addiction, inattention, novelty-seeking, and harm-avoidance. Four genetic loci including DRD4 VNTR, DRD2 Taq1A, COMT Val158Met and 5-HTTLPR length polymorphisms were screened from seventy-three individuals. Our results showed that the DRD4 4R/4R individuals scored significantly higher than the $2 \mathrm{R}$ or $7 \mathrm{R}$ carriers in Internet Addiction Test (IAT). The 5-HTTLPR short/short males scored significantly higher in IAT than the long variant carriers. Bayesian analysis showed the most compatible hypothesis with the observed genetic results was based on attention $(69.8 \%)$, whereas hypotheses based harm-avoidance $(21.6 \%)$, novelty-seeking $(7.8 \%)$ and addiction $(0.9 \%)$ received little support. Our study suggests that carriers of alleles (DRD4 2R and 7R, 5-HTTLPR long) associated with inattentiveness are more likely to experience disrupted patterns and reduced

durations of Internet use, protecting them from Internet overuse. Furthermore, our study suggests that Internet overuse should be categorized differently from addiction due to the lack of shared genetic contributions.

Keywords: Internet overuse; inattentiveness; dopamine receptor D4 gene (DRD4); serotonin transporter gene (5HTTLPR); Internet Addiction Test 


\section{Introduction}

The advent of the Internet age in the last decade provided the world with new landscapes of sociability and access. Lately, the growing role of the Internet, along with other new information technologies (e.g., mobile devices and applications), has become increasingly pervasive and influential in all aspects of our everyday life. With its impersonal method of communication, copious amount of information, and many other unprecedented features, the Internet has reshaped and redefined friendships, businesses, professions, academia, and entertainment. Meanwhile, the omnipresent Internet has created serious social and personal problems, everything from privacy theft (Aimeur \& Schonfeld, 2011) and cyberbullying (Tokunaga, 2010) to Internet overuse.

\section{Is Internet Overuse a Type of Addiction?}

Since the term "Internet addiction" was first introduced in 1996 (Young, 1996), there has been considerable debate by both clinicians and academicians over whether it should be diagnosed, studied, and treated the same way as substance addictions such as alcohol, nicotine and drugs (Beard \& Wolf, 2001; Campbell, Cumming, \& Hughes, 2006; Mitchell, 2000; Murali \& George, 2007; Young, 2004). The discussion has become even more contentious after pathological gambling became the first behavioral disorder recognized as a type of addiction by the American Psychiatric Association (2013). The controversy is also reflected in the use of terminologies. Besides Internet addiction, some refer to it as Internet addiction disorder (Bai, Lin, \& Chen, 2001), whereas others prefer pathological Internet use (Morahan-Martin \& Schumacher, 2000), or Internet dependency (W. Wang, 2001). In this study, the term Internet overuse is used to cover the collective phenomenon.

Despite the debate and controversy, Internet overuse became a popular topic for research. Between 1996 and 2006, more than 120 peer-reviewed articles were published on Internet overuse and related subjects (Byun et al., 2009). Internet overuse has been most studied in East Asian countries such as China and South Korea (Weinstein \& Lejoyeux, 2010). This seems to correspond with the high prevalence of Internet overuse and frequent tragic incidents related to Internet overuse in this region (Choi et al., 2009; Deng \& Xuan, 2009; Lam, Peng, Mai, \& Jing, 2009; Park, Kim, \& Cho, 2008; Tsai et al., 2009). Internet overuse was also first codified within the psychopathological framework in East Asian countries (Block, 2008). However, due to the inconsistent criteria, there is a lack of standardized instrument for measuring Internet overuse across study findings and cultural perspectives.

\section{Internet Use in College}

College students are one of the most studied populations worldwide on Internet use. Compared to the general public, college students have relatively independent control of their leisure time and unfettered access to the Internet (Christakis, Moreno, Jelenchick, Myaing, \& Zhou, 2011). Moreover, the fast growing popularity of social networking sites (e.g., Facebook and Instagram) among college students (Pempek, Yermolayeva, \& Calvert, 2009) and use of online teaching tools (e.g., Blackboard) on college campuses have made frequent access to the Internet almost indispensable. In the US, almost all college students (90\%) use the Internet on a daily basis (Fortson, Scotti, Chen, Malone, \& Del Ben, 2007), spending an average of 3.3 hours online per day (Rotunda, Kass, Sutton, \& Leon, 2003). Using various survey instruments, the rates of Internet overuse among college students range from 1.1\% to 17.9\% globally, with the highest reported in East Asia (Alavi, Maracy, Jannatifard, \& Eslami, 2011; Goel, Subramanyam, \& Kamath, 2013; Jelenchick, Becker, \& Moreno, 2012; Lin, Ko, \& Wu, 2011; Muñoz-Rivas, Fernández, \& GámezGuadix, 2010; Ni, Yan, Chen, \& Liu, 2009; Niculović, Živković, Manasijević, \& Štrbac, 2012; Saville, Gisbert, Kopp, \& Telesco, 2009; H. F. Tsai et al., 2009). Several studies reported higher total use of the Internet in males than in females (Joiner et al., 2005; Odell, Korgen, Schumacher, 
\& Delucchi, 2000). Male college students are more likely to use the Internet for information and entertainment such as reading news, playing online video games, listening to music and downloading music/videos; female college students are more likely to use the Internet for communicative purposes like e-mail and social networking sites (Jackson, Ervin, Gardner, \& Schmitt, 2001; Joiner et al., 2005; Jones, Johnson-Yale, Millermaier, \& Pérez, 2009; Odell et al., 2000; Tufekci, 2008). Men have a more positive attitude towards the Internet, experience less anxiety, and feel more comfortable during Internet use than women (Jackson et al., 2001; Sherman et al., 2000; Slate, Manuel, \& Brinson, 2002; Zhang, 2002). Findings from several studies around the world have indicated higher risk for Internet overuse among male college students than females (Alavi et al., 2011; Ko, Yen, Yen, Chen, \& Chen, 2008; Muñoz-Rivas et al., 2010; Yen, Yen, Chen, Tang, \& Ko, 2009).

\section{Genes and Internet Overuse}

There were three studies investigating genetic susceptibilities to Internet overuse as of 2014. They reported associations between Internet overuse and genetic polymorphisms related to dopaminergic (Han et al., 2007), serotonergic (Y. S. Lee et al., 2008) and nicotinic pathways (Montag et al., 2012).

Dopamine D2 receptor gene (DRD2) encodes the D2 subtype of the dopamine receptor which is related to cognitive functions such as response inhibition, temporal organization of material, and motor performance (Cropley, Fujita, Innis, \& Nathan, 2006). Variations of the Taq1A locus have been the most studied polymorphism of DRD2 (Noble, 2003) with carriers of the A1 allele expressing significantly reduced D2 dopamine binding sites compared to carriers of the A2 allele (Pohjalainen et al., 1998). Han et al. (2007) found that more individuals with the A1 allele played online video game for an extended period to compensate for the deficiencies in their dopamine system.

Catechol-O-methyl transferase (COMT) is an enzyme that degrades and inactivates catechol neurotransmitters such as dopamine (Grossman, Emanuel, \& Budarf, 1992). A functional singlenucleotide polymorphism of the COMT gene results in a valine to methionine mutation at position 158 (Val158Met polymorphism) which leads to a 3 to 4-fold reduction in enzymatic activity (Lachman et al., 1996). Han et al. (2007) suggested that the low inactivation rate of dopamine associated with the low-activity variant lead to a raised feeling of euphoria from playing online video games.

The serotonin reuptake transporter (5-HTT) transports serotonin from the synaptic cleft to the presynaptic neuron. Transcription of the gene is modulated by the 5-HTT gene-linked polymorphic region (5-HTTLPR), which contains an insertion/deletion polymorphism (Nakamura, Ueno, Sano, \& Tanabe, 2000). The basal activity of the short variant is about 3-fold lower than the long variant (Heils et al., 1996) and the allele frequency varies globally (Gelernter, Cubells, Kidd, Pakstis, \& Kidd, 1999). Y. S. Lee et al. (2008) reported higher risk for Internet overuse among individuals with homozygous short alleles.

Neuronal acetylcholine receptor subunit alpha-4 is a protein encoded by the CHRNA4 (cholinergic receptor-nicotinic-alpha 4) gene. Although the functionality of the rs1044396 polymorphism in the CHRNA4 gene is still unclear, the effect has been implicated in anxiety (Markett, Montag, $\&$ Reuter, 2011) and addiction (Feng et al., 2004) studies. Montag et al. (2012) reported that the $\mathrm{CC}$ genotype of the polymorphism occurred significantly more frequently in the group with Internet overuse problems.

Although dopamine D4 receptor gene (DRD4) has been widely studied for a variety of behavioral processes such as addiction, attention deficit hyperactivity disorder (ADHD), novelty-seeking and harm-avoidance, no previous studies have investigated its relationship with Internet overuse. The 
gene encodes a transmembrane G-protein coupled receptor - dopamine D4 receptor (McGeary, 2009) which mediates inhibitory impacts on neuronal firing in dopaminergic pathway (Rubinstein et al., 2001; E. Wang et al., 2004). DRD4 gene contains a variable number of tandem repeat (VNTR) polymorphism in exon 3 that consists of a 48-bp repeat unit. This unit is repeated between 2 and 11 times with the most common versions being 4 (4R), 7 (7R) and 2 (2R) repeats (McGeary, 2009; Van Tol et al., 1992). Compared to the 4R, both the 2R and 7R variants mediate a blunted intracellular response to dopamine (Asghari et al., 1995; E. Wang et al., 2004) and manifest similar phenotypic effects in behavioral processes such as addiction and ADHD (Comings et al., 1999). The frequencies of the $4 \mathrm{R}$ and $7 \mathrm{R}$ differ considerably across populations (Chang, Kidd, Livak, Pakstis, \& Kidd, 1996), a possible result of a positive selection of the 7R related to human migration (Chen, Burton, Greenberger, \& Dmitrieva, 1999; Ding et al., 2002).

\section{Genes in Other Behavioral Processes}

As the Internet becomes more pervasive in all aspects of modern life, a better conceptualization of Internet overuse will help us to minimize its harm. The field may benefit from lessons and experience in the nosological changes of pathological gambling. It was only until recently that pathological gambling was placed in the same category related to substance addiction in DSM, rather than categorized as impulse-control disorders. Among the similarities between pathological gambling and substance addiction, common underlying genetic vulnerabilities have contributed significantly to the change of classification. Exploring the established connections between genetics (i.e., DRD4, DRD2, COMT and 5-HTTLPR polymorphisms) and behaviors may offer new insights into the understanding of Internet overuse.

\section{Addiction}

Addictions are chronic disorders often characterized by obsession, compulsion, and physi$\mathrm{cal} /$ psychological dependence on psychoactive substances or behaviors. Genetic factors affect all steps of addiction from vulnerability at initiation to likelihood of becoming dependent (M. D. Li $\&$ Burmeister, 2009). Strong evidence emerged from previous studies including meta-analyses and review studies that DRD4 2R and 7R, and DRD2 A1 alleles were associated with higher risks for substance and behavioral addictions (Comings et al., 1996, 1999; Le Foll, Gallo, Le Strat, Lu, \& Gorwood, 2009; McGeary, 2009; Noble, 2000, 2003). In contrast, results from studies on COMT and 5-HTTLPR polymorphisms were mixed and inconsistent (Dick \& Foroud, 2003; Ducci \& Goldman, 2012; Hosák, 2007; Köhnke, 2008; Serretti, Calati, Mandelli, \& De Ronchi, 2006; Tammimäki \& Männistö, 2010; Verdejo-García, Lawrence, \& Clark, 2008).

\section{Inattention (ADHD)}

ADHD is a condition with inattentiveness, over-activity, impulsivity, or a combination (Schweitzer, Cummins, \& Kant, 2001; Whalen \& Henker, 1998). These components might be evolutionarily adaptive in ancestral environments such as hunter-gatherer or nomadic societies (Jensen et al., 1997) but problematic under less-dynamic settings such as a settled food-producing community or classroom learning (Eisenberg, Campbell, Gray, \& Sorenson, 2008). Previous studies revealed strong evidence that DRD4 4R and 5-HTTLPR short alleles are associated with decreased risk for inattention (Faraone, Doyle, Mick, \& Biederman, 2001; Faraone et al., 2005; Gizer, Ficks, \& Waldman, 2009; Kebir \& Joober, 2011; Kent et al., 2002; Khan \& Faraone, 2006; Leung et al., 2005; D. Li, Sham, Owen, \& He, 2006; Wu, Xiao, Sun, Zou, \& Zhu, 2012). Existing data on relationships between DRD2 and inattention are mixed and conflicting as associations with each allele and non-association all have been reported (Bobb, Castellanos, Addington, \& Rapoport, 2006; Gizer et al., 2009; Wu et al., 2012). The role of COMT was less ambiguous as 
most studies including meta-analyses found no connections between the Val158Met polymorphism and inattention (Faraone et al., 2005; Gizer et al., 2009; Hosák, 2007).

\section{Novelty-seeking}

Novelty-seeking is one of the seven personality dimensions of human temperament often measured using the Temperament and Character Inventory (Cloninger, 1993). Individuals with greater novelty-seeking personality are often described as exploratory, curious, inquisitive, and enthusiastic (Kose, 2003). Strong evidence emerged from existing studies that the polymorphisms in DRD4, DRD2 and 5-HTTLPR were not connected to novelty-seeking personality (Burt, McGue, Iacono, Comings, \& MacMurray, 2002; de Brettes et al., 1998; Ebstein, 2006; Ebstein et al., 1997; Hill, Zezza, Wipprecht, Locke, \& Neiswanger, 1999; Kluger, Siegfried, \& Ebstein, 2002; Kreek, Nielsen, Butelman, \& LaForge, 2005; S. H. Lee, Ham, Cho, Lee, \& Shim, 2007; Light et al., 2007; Munafò et al., 2003; Ricketts et al., 1998; Samochowiec et al., 2001; Schinka, Letsch, \& Crawford, 2002; Suzuki et al., 2008; Tsuchimine et al., 2012; Van Gestel et al., 2002). In contrast, studies on COMT polymorphism revealed mixed and conflicting results (Calati et al., 2011; Demetrovics et al., 2010; Golimbet, Alfimova, Gritsenko, \& Ebstein, 2007; Hashimoto et al., 2007; Hosák, Libiger, Cizek, Beránek, \& Cermáková, 2006; Hoth et al., 2006; Kim, Kim, Kim, Lee, \& Kim, 2006; Lichtenberg, Bachner-Melman, Ebstein, \& Crawford, 2004; Light et al., 2007; Reuter \& Hennig, 2005; S.-J.Tsai, Hong, Yu, \& Chen, 2004).

\section{Harm-avoidance}

Harm avoidance is another personality dimension of human temperament. Individuals with greater harm-avoidance or lesser risk-taking personality tend to be cautious, fearful, nervous, discouraged, doubtful, inhibited, and shy in most social situations (Kose, 2003). Studies on the DRD4, DRD2 and COMT polymorphisms revealed mixed and conflicting results (Bau, Roman, Almeida, \& Hutz, 1999; Dreber et al., 2009; Enoch, Xu, Ferro, Harris, \& Goldman, 2003; Golimbet et al., 2007; Hashimoto et al., 2007; Hill et al., 1999; Kim et al., 2006; Kuhnen \& Chiao, 2009; Lee et al., 2007; Lichtenberg et al., 2004; Light et al., 2007; Munafò et al., 2003; Serretti, Mandelli, et al., 2006; Smolka et al., 2005; Tsai et al., 2004; Tsuchimine et al., 2012). Meta-analyses and review studies indicated that there was no connection between 5-HTTLPR polymorphism and harm-avoidance personality (Ebstein, 2006; Munafò et al., 2009; Schinka, Busch, \& RobichauxKeene, 2004; Sen, Burmeister, \& Ghosh, 2004).

\section{Research Objective and Hypotheses}

As the study of Internet overuse is still at its preliminary stage, there is an increasing need for exploratory studies to gain insights on genetic basis of Internet overuse and to offer refined hypotheses for future investigations. The present study investigated whether genetic polymorphisms in DRD4, DRD2, COMT and 5-HTTLPR are linked to Internet overuse through one (or several) of the four behavioral processes: addiction, attention, novelty-seeking, and harm-avoidance. The following four hypotheses, each based on one of the behavioral processes, were proposed and evaluated using a method of Bayesian analysis. First, if the etiology of Internet overuse is similar to addiction, carriers of the risk alleles for addiction (DRD4 2R, 7R and DRD2 A1) should have higher risk for Internet overuse compared to their counterparts. Second, if the inattentiveness and hyperactivity lead to disrupted patterns and decreased durations of Internet use, carriers of alleles associated with attention (DRD4 4R and 5-HTTLPR short alleles) should have higher risk for Internet overuse. Third, if exploratory, curious, and inquisitive individuals consider the Internet as a place with innumerable novel stimuli and excitements, carriers of the alleles associated noveltyseeking personality should spend more time exploring online novelties and thus are more likely to have Internet overuse problems. Fourth, if cautious, fearful, and socially shy individuals regard 
the Internet as a risk-free and socially-comfortable environment, carriers of the alleles associated with harm-avoidance personality would spend more time online to avoid the physical world and have higher risk for Internet overuse.

\section{Research Methodology}

Participants were recruited for AFK (away-from keyboard) Weekend Project at Binghamton University in April 2011. The event was advertised via campus flyers and listserv postings. Each participant was given a chance to win one of four Amazon.com gift cards in a lottery. This study was conducted in accordance with guidelines for the use of humans as research participants and was approved by the Human Subjects Research Review Committee at Binghamton University. All participants were adults ( $\geq 18$ years) and enrolled voluntarily. A written informed consent was given based on a clear understanding and appreciation of the procedure and implications of the project prior to their participation.

\section{Self-report Survey and AFK Procedure}

Primary self-report measures of this study consisted of a pre-weekend survey on Friday, a log kept by the participants on Saturday (24-hr Internet abstinence) and Sunday, and a post-weekend survey on Monday. DNA samples were collected from participants during the initial enrollment. The pre-weekend survey consisted of questions regarding participants' general Internet use patterns (including the frequencies of Internet use and the average amount of time using Internet per day as well as in a single session) and frequencies they participated in twelve online activities. The population-level frequency of use for the twelve activities was defined as the proportion of the population participating on a weekly basis.

After completing the pre-weekend survey on Friday, the participants were asked to abstain from using the Internet (via computers and mobile devices) for 24 hours the next day (Saturday). On Sunday (starting at 12AM), the participants were allowed to resume regular Internet use. Every three waking hours on both weekend days, the participants were asked to record their activities and moods in a provided logbook. On Monday, participants returned to complete the postweekend survey which consisted of questions regarding their use of mobile devices, mobile applications, and the Internet Addiction Test (IAT). The IAT has been widely used globally to evaluate risk for Internet overuse by examining the degree of preoccupation, compulsive use, behavioral problems, emotional changes, and the impact on life resulting from Internet use. The test consists of 20 questions (100 points in total), with each response measured on a six-point Likert scale (Young, 1998a). The higher the total score is, the more inferred problems are caused by Internet overuse.

Considering that several questions in IAT address psychological responses when access to the Internet becomes unavailable, the requirement of 24-hr Internet abstinence before answering the IAT in the present study was to ensure a more realistic and accurate self-evaluation. We think this is essential to all studies using similar measures because self-prejudices resulting from routine interactions with the Internet might impair the accuracy of the IAT scores.

\section{Genotyping}

For DNA analysis, a non-invasive oral buccal wash sample was obtained from each participant using $10 \mathrm{ml}$ of Scope ${ }^{\mathrm{TM}}$ mouthwash (Feigelson et al., 2001). The buccal cell samples were extracted and analyzed in the Laboratory of Evolutionary Anthropology and Health at Binghamton University. Four genetic loci were screened, including DRD4 exon 3 VNTR, DRD2 Taq1A, COMT Val158Met and 5-HTTLPR length polymorphisms. Genotypes were grouped for analyses as follows: DRD4 4R (high-activity) homozygotes (4R group) and 2R or 7R (low-activity) carri- 
ers (2R/7R group), DRD2 A2 allele (high-activity) homozygotes and A1 allele (low-activity) carriers, COMT high-activity $(\mathrm{H})$ variant homozygotes and low-activity $(\mathrm{L})$ variant carriers, and 5HTTLPR high-activity long allele (1) carriers and low-activity short allele (s) homozygotes.

\section{Statistical Analysis}

For the pre-weekend survey, gender differences in frequency of Internet use (e.g., several times a day, once a day and so on) was analyzed using chi-squared test. Gender differences in average time spent on the Internet per day (hrs) and in a single session (e.g., $<1 \mathrm{hr}, 1 \sim 2 \mathrm{hrs}$, etc.) were analyzed using independent t-test and chi-squared test respectively. Proportions of participants from each gender spending over three hours online per day were compared using chi-squared test. Chi-squared tests were also used to analyze gender difference in the frequency of use in each online activity. The numbers of online activities engaged on a weekly basis were compared between genders using independent t-test. Differences between genotypes of each locus were analyzed using the same methods for gender comparisons. For the post-weekend survey, both gender and genotype differences in IAT scores were analyzed using independent t-tests. Effects of interactions between gender and genotypes were also explored. Pearson product-moment correlation was used to analyze the relationship between IAT scores and time spent on the Internet per day (recorded in the pre-weekend survey). Statistical significance was defined at an alpha level $<0.05$.

\section{Hypotheses Testing}

We use Bayesian analysis to evaluate fit between observed genetic results and each hypothesis. The procedure is similar to what Ogino and Wilson (2004) described for risk assessment in genetic counseling and testing. Because no existing consensus has indicated any of the four models explains Internet overuse better than the others, the prior probabilities $(0.25)$ are equal across them. The conditional probability for each model is the probability that the observed results occur if we assume that hypothesis is true. Because there are four independent genetic associations (or non-associations) with Internet overuse, the conditional probability for each model is calculated by multiplying the likelihoods of each genetic association assuming that hypothesis is true. The likelihood for each genetic association is determined based on reviewing previous meta-analyses, reviews and association studies. For example, under the attention model, individuals carrying the alleles associated with higher attentiveness have higher risk for Internet overuse. The majority of studies found DRD4 4R was associated with greater attentiveness compared to $2 \mathrm{R}$ and $7 \mathrm{R}$. If our results reveal that DRD4 4R group scores higher on average in IAT meaning greater risk for Internet overuse, we would assign a likelihood of 0.9 to this association. This method of assigning likelihoods based on degrees of epistemic confidence in existing data is widely applied (Cooke, 1991; de Elía \& Laprise, 2005; Jeffrey, 2004; Siu \& Kelly, 1998; Spiegelhalter, Franklin, \& Bull, 2013; Vick, 2002; Wacholder, Chanock, Garcia-Closas, El Ghormli, \& Rothman, 2004) because of its advantage in clarifying roles of important but difficult-to-assess factors (Jackman, 2009; Stephens \& Balding, 2009). More information regarding the literature reviewed and how the likelihood for each genetic association was determined is provided in the Appendix. The next step of the Bayesian analysis is the joint probability for each hypothesis, which results from multiplying the prior and conditional probabilities. The final step of the Bayesian analysis is the posterior probability, which is calculated by dividing the joint probability for that hypothesis by the sum of all of the joint probabilities. 


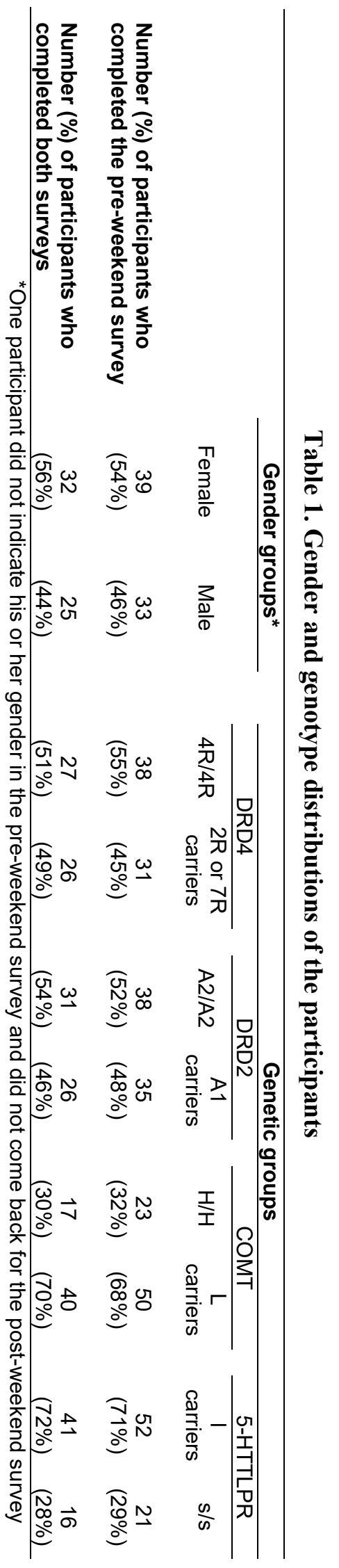




\section{Results}

Seventy-three participants consisting of fifty-eight undergraduate students $(80 \%)$, fourteen graduate students (19\%) and one university staff $(1 \%)$, with an average age of $21.7(\mathrm{SD}=4.1)$ completed the initial enrollment, the pre-weekend survey, and donated their DNA samples on the AFK Friday. On the following Monday, fifty-seven participants consisting of forty-five undergraduate (79\%), eleven (19\%) graduate students and one university staff $(1 \%)$ returned, handed in their logbooks, and completed the post-weekend survey. The only university staff was kept in the sample because the inclusion did not lead to substantial changes to the following analyses and conclusions. Chi-squared tests showed that the participants who returned on Monday shared the same gender and genotype distributions with the participants at the initial enrollment on Friday (Table 1. gender: $\chi^{2}(1, \mathrm{n}=129)=0.05, \mathrm{p}=0.820$; DRD4: $\chi^{2}(1, \mathrm{n}=122)=0.21, \mathrm{p}=0.651 ; \mathrm{DRD} 2: \chi^{2}(1$, $\mathrm{n}=130)=0.07, \mathrm{p}=0.792$; COMT: $\chi^{2}(1, \mathrm{n}=130)=0.04, \mathrm{p}=0.837 ;$ 5-HTTLPR: $\chi^{2}(1, \mathrm{n}=130)=0.01$, $\mathrm{p}=0.930)$.

Table 2. Internet use patterns among college students and gender difference.

\begin{tabular}{|c|c|c|c|c|}
\hline & $\begin{array}{c}\text { All } \\
\left(\mathrm{N}=73^{*}\right)\end{array}$ & $\begin{array}{c}\text { Female } \\
(n=39)\end{array}$ & $\begin{array}{c}\text { Male } \\
(n=33)\end{array}$ & $p$ \\
\hline $\begin{array}{l}\text { - Average time spent on the Internet per day } \\
\text { (hrs) }\end{array}$ & $3.8 \pm 2.0$ & $3.6 \pm 2.0$ & $4.2 \pm 2.1$ & 0.160 \\
\hline
\end{tabular}

- Percent of participants:

spending over three hours online on average per

day spending over one hour online on average in a single session

$\begin{array}{llll}45 \% & 41 \% & 52 \% & 0.373 \\ 70 \% & 64 \% & 76 \% & 0.287\end{array}$

- Frequency of use for each online activity:

\begin{abstract}
Use search engines for information Check social networking sites Read news online Watch TV shows or movies Chat with others online Search and buy songs or music online Download TV shows or movies Play social network games Video chat with others Shop online

Play online multiplayer video games Write online blogs
\end{abstract}

- Number of types of online activities on a weekly basis

$\begin{array}{cccc}100 \% & 100 \% & 100 \% & \text { NA } \\ 89 \% & 87 \% & 91 \% & 0.616 \\ 82 \% & 74 \% & 91 \% & 0.069 \\ 74 \% & 74 \% & 73 \% & 0.876 \\ 71 \% & 72 \% & 70 \% & 0.845 \\ 37 \% & \mathbf{2 6 \%} & \mathbf{4 8 \%} & \mathbf{0 . 0 4 4} \\ 33 \% & \mathbf{1 3 \%} & \mathbf{5 5 \%} & <0.001 \\ 29 \% & 28 \% & 30 \% & 0.845 \\ 21 \% & 21 \% & 21 \% & 0.942 \\ 21 \% & 13 \% & 30 \% & 0.069 \\ 16 \% & 3 \% & 33 \% & <0.001 \\ 4 \% & 5 \% & 3 \% & 0.657\end{array}$

${ }^{\star}$ Seventy-two participants provided their gender information

\section{Pre-weekend Survey}

Almost all participants (99\%) used the Internet multiple times per day, with an average total time of $3.8 \mathrm{hrs}(\mathrm{SD}=2.0)$. Seventy percent of the participants indicated the average time spent on the Internet in a single session was over one hour. Frequency of use for the twelve online activities varied from using search engines for information (100\%) to writing online blogs $(4 \%)$ (Table 2$)$. 
Five prevalent activities, mainly ones dealing with communication (e.g., using social networking sites) and information (e.g., using search engines), had frequency of use over 70\%. The rest, mainly forms of entertainment (e.g., online gaming and shopping), had frequency of use less than $40 \%$.

Thirty-three males (46\%) and thirty-nine females (54\%) completed the pre-weekend survey. Our results showed that on average the males spent $4.2 \mathrm{hrs}(\mathrm{SD}=2.0)$ and the females spent $3.6 \mathrm{hrs}$ $(\mathrm{SD}=2.0)$ on the Internet per day, $\mathrm{t}(70)=1.42, \mathrm{p}=0.160$. Most males $(76 \%)$ and females $(64 \%)$ spent more than one hour on the Internet on average in a single session and no significant difference was found between genders, $\chi^{2}(1, n=72)=1.14, p=0.285$. The males participated in more types of online activities on a weekly basis $(7.6, \mathrm{SD}=2.2)$ than the females $(6.2, \mathrm{SD}=1.7)$, $t(70)=3.08, p=0.003$. Comparisons of the frequency of use in three online activities showed significant gender differences: more males than females searched and bought songs or music online $\left(48 \%\right.$ vs. $\left.26 \% ; \chi^{2}(1, n=72)=4.04, p=0.044\right)$, downloaded movies/shows $\left(55 \%\right.$ vs. $13 \% ; \chi^{2}(1$, $\mathrm{n}=72)=14.32, \mathrm{p}<0.001)$, and played online multiplayer video games $\left(33 \%\right.$ vs. $3 \% ; \chi^{2}(1$, $\mathrm{n}=72)=12.19, \mathrm{p}<0.001)$.

When using average daily time spent on the Internet as a proxy for the severity of Internet overuse, male (52\%) and female (41\%) participants were equally likely to spend more than three hours online per day, $\chi^{2}(1, \mathrm{~N}=72)=0.79, \mathrm{p}=0.373$. The validity of this proxy was justified later by the positive correlation between IAT scores and daily time spent on the Internet.

Four genetic loci (DRD4, DRD2, COMT and 5-HTTLPR) were screened and their genotypes were compared to participants' responses in the pre-weekend survey. None of the loci were associated with time spent on the Internet per day $(\mathrm{DRD} 4: \mathrm{t}(67)=0.62, \mathrm{p}=0.536$; $\mathrm{DRD} 2: \mathrm{t}(71)=0.83$, $\mathrm{p}=0.409$; COMT: $\mathrm{t}(71)=0.30, \mathrm{p}=0.762 ; 5$-HTTLPR: $\mathrm{t}(71)=0.91, \mathrm{p}=0.366)$. More participants from the DRD4 4R group (79\%) spent over an hour on the Internet in a single session compared to the $2 \mathrm{R} / 7 \mathrm{R}$ group $(58 \%), \chi^{2}(1, \mathrm{n}=69)=3.52, \mathrm{p}=0.061$. Participants with homozygous COMT H alleles participated in more types of online activities on a weekly basis $(7.6, \mathrm{SD}=2.1)$ than the $\mathrm{L}$ allele carriers $(6.6, \mathrm{SD}=2.0), \mathrm{t}(71)=2.00, \mathrm{p}=0.049$. Frequency of use for "search and buy songs or music online" was higher among participants with homozygous COMT H alleles (57\%) than the L allele carriers $(28 \%), \chi^{2}(1, n=73)=5.50, p=0.019$.

None of the loci were associated with the likelihood of spending more than three hours online per day $\left(\right.$ DRD4: $\chi^{2}(1, \mathrm{n}=69)=0.20, \mathrm{p}=0.652 ;$ DRD2: $\chi^{2}(1, \mathrm{n}=73)=1.77, \mathrm{p}=0.184$; COMT: $\chi^{2}(1$, $\mathrm{n}=73)=0.66, \mathrm{p}=0.417$; 5-HTTLPR: $\left.\chi^{2}(1, \mathrm{n}=73)=0.61, \mathrm{p}=0.434\right)$. When analyzed by gender, more male participants in the DRD4 4R group (67\%) spent more than three hours online than the $2 \mathrm{R} / 7 \mathrm{R}$ group $(31 \%), \chi^{2}(1, \mathrm{n}=31)=3.89, \mathrm{p}=0.049$. But this was not found among female participants $\left(36 \%\right.$ vs. $\left.43 \%, \chi^{2}(1, n=37)=1.05, \mathrm{p}=0.306\right)$.

\section{Post-weekend Survey}

Among the fifty-seven participants who returned for the post-weekend survey, fifty-six participants $(99 \%)$ completed the IAT with an average score of $31.5(\mathrm{SD}=9.3)$. No participants were categorized as users with significant problems (IAT $\geq 80$ ), while two (4\%) were categorized as users with occasional problems $(50 \leq \mathrm{IAT}<80)$. Analysis showed IAT scores correlated positively with average time spent on the Internet per day $(r=0.29, n=56, p=0.030)$.

The male participants scored an average of $32.6(\mathrm{SD}=8.0)$ in the IAT, similar with female's 30.7 $(\mathrm{SD}=10.2), \mathrm{t}(54)=0.78, \mathrm{p}=0.439$. Comparisons between the genotypes of DRD2 (30.6 vs. 32.3) and COMT (31.2 vs. 32.2) revealed no significant differences in IAT scores (DRD2: $\mathrm{t}(54)=0.69$, $\mathrm{p}=0.495$; COMT: $\mathrm{t}(54)=0.39, \mathrm{p}=0.700)$. The $\mathrm{DRD} 4$ 4R group (35.1, $\mathrm{SD}=9.8)$ scored significantly higher than the $2 \mathrm{R} / 7 \mathrm{R}$ group $(27.8, \mathrm{SD}=7.3$ ) in the IAT, $\mathrm{t}(50)=3.00, \mathrm{p}=0.004$ (Figure 1). When analyzed by gender, the females in DRD4 4R group (34.9, $\mathrm{SD}=10.2)$ scored significantly higher 
than the $2 \mathrm{R} / 7 \mathrm{R}$ group $(26.2, \mathrm{SD}=8.1), \mathrm{t}(28)=2.52, \mathrm{p}=0.018$. The males in $\mathrm{DRD} 44 \mathrm{R}$ group (35.3, $\mathrm{SD}=9.6)$ also scored higher than the $2 \mathrm{R} / 7 \mathrm{R}$ group $(29.6, \mathrm{SD}=6.3)$ but the difference was not statistically significant, $\mathrm{t}(20)=1.69, \mathrm{p}=0.107$. The males with homozygous 5-HTTLPR s alleles (39.0, $\mathrm{SD}=9.8)$ scored higher in the IAT than the 1 allele carriers $(31.0, \mathrm{SD}=6.8), \mathrm{t}(22)=2.14, \mathrm{p}=0.043$. But this was not found in females $(\mathrm{t}(30)=0.50, \mathrm{p}=0.624)$. Overall, participants with homozygous $\mathrm{s}$ alleles (34.1, $\mathrm{SD}=10.9)$ scored higher than 1 allele carriers $(30.5, \mathrm{SD}=8.5)$, but the difference was statistically non-significant, $\mathrm{t}(54)=1.34, \mathrm{p}=0.185$.

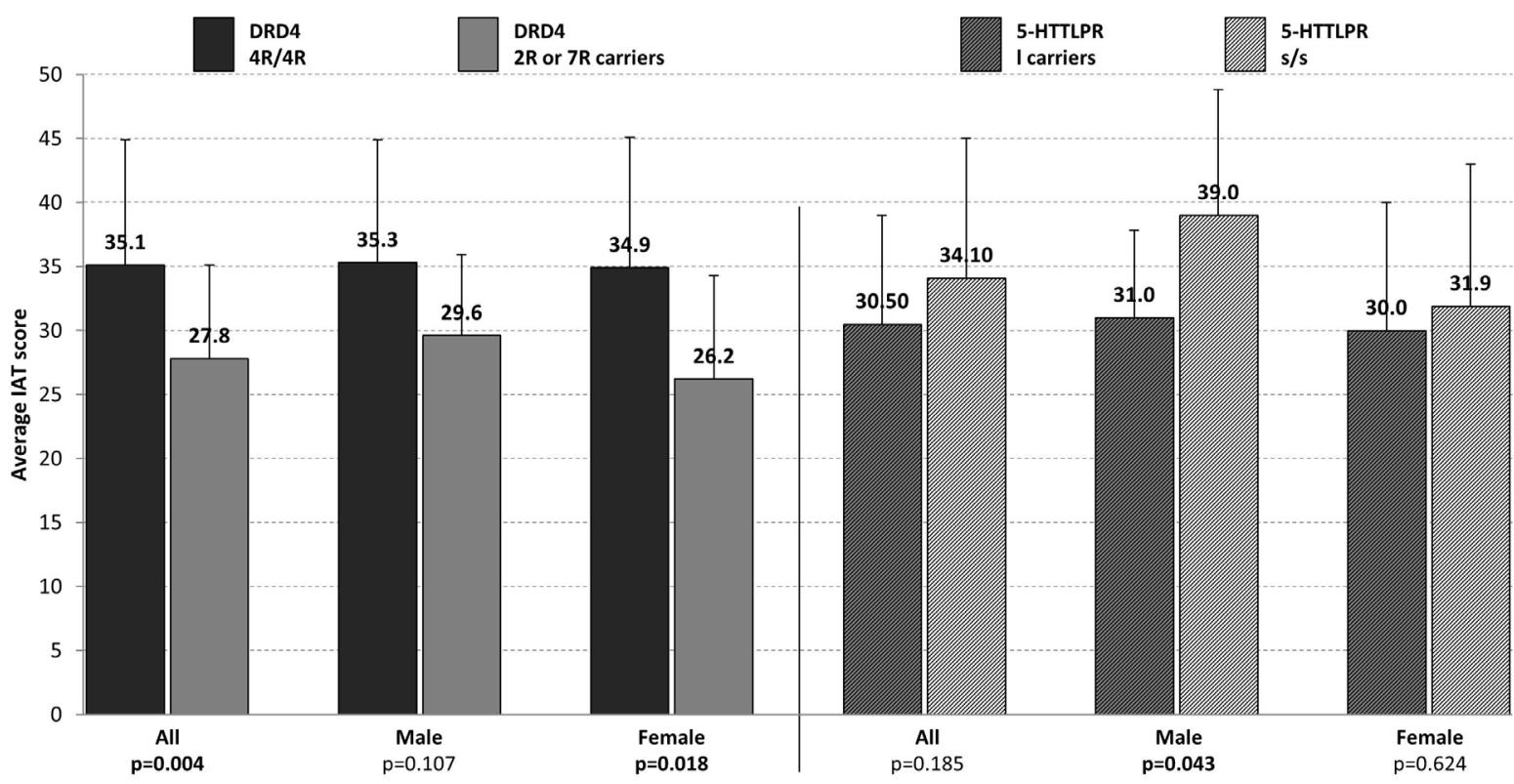

Figure 1. Comparison of Internet Addiction Test (IAT) score (mean and standard deviation). Left: DRD4 homozygous 4R carriers vs 2R or 7R carriers. Right: 5-HTTLPR long allele carriers vs homozygous short allele carriers.

\section{Hypotheses Testing}

The Bayesian analysis (Table 3) showed that the four hypotheses varied in their levels of agreeableness with the observed results. The best-fit hypothesis was based on the attention model $(69.8 \%)$, whereas hypotheses based on the harm-avoidance $(21.6 \%)$, the novelty-seeking $(7.8 \%)$ and the addiction models $(0.9 \%)$ received little support.

\section{Discussion}

Using the Bayesian analysis, the present study evaluated four hypotheses regarding how four genetic loci (DRD4 exon 3 VNTR, DRD2 Taq1A, COMT Val158Met and 5-HTTLPR length polymorphisms) were linked to Internet overuse through one of the four behavioral processes: addiction, attention, novelty-seeking and harm-avoidance. The existing knowledge on the genetic associations with those behavioral processes were used to provide valuable insights into Internet overuse, as well as developing tentative hypotheses for future investigations. 
Table 3. Use of Bayesian analysis to evaluate four hypotheses linking Internet overuse and its genetic contributions. Each hypothesis was based on existing knowledge of genetic predispositions to addiction, attention, novelty-seeking and harm-avoidance.

\begin{tabular}{|c|c|c|c|c|c|c|}
\hline \multirow{4}{*}{$\begin{array}{l}\text { Hypothesis } \\
\text { Addiction }\end{array}$} & \multirow{4}{*}{$\begin{array}{c}\begin{array}{c}\text { Prior prob- } \\
\text { ability }\end{array} \\
\\
0.25\end{array}$} & \multicolumn{2}{|c|}{$\begin{array}{l}\text { Likelihood for } \\
\text { each association }\end{array}$} & \multirow{5}{*}{$\begin{array}{c}\begin{array}{c}\text { Conditional } \\
\text { probability }\end{array} \\
0.0025\end{array}$} & \multirow{5}{*}{$\begin{array}{c}\begin{array}{c}\text { Joint } \\
\text { probability }\end{array} \\
0.000625\end{array}$} & \multirow{5}{*}{$\begin{array}{c}\begin{array}{c}\text { Posterior } \\
\text { probability }\end{array} \\
0.9 \%\end{array}$} \\
\hline & & DRD4 & 0.1 & & & \\
\hline & & DRD2 & 0.1 & & & \\
\hline & & СOMT & 0.5 & & & \\
\hline & & 5-HTTLPR & 0.5 & & & \\
\hline \multirow{4}{*}{ Attention } & \multirow{4}{*}{0.25} & DRD4 & 0.9 & \multirow{4}{*}{0.2025} & \multirow{4}{*}{0.050625} & \multirow{4}{*}{$69.8 \%$} \\
\hline & & DRD2 & 0.5 & & & \\
\hline & & СOMT & 0.9 & & & \\
\hline & & 5-HTTLPR & 0.5 & & & \\
\hline \multirow{4}{*}{$\begin{array}{l}\text { Novelty- } \\
\text { seeking }\end{array}$} & \multirow{4}{*}{0.25} & DRD4 & 0.1 & \multirow{4}{*}{0.0225} & \multirow{4}{*}{0.005625} & \multirow{4}{*}{$7.8 \%$} \\
\hline & & DRD2 & 0.9 & & & \\
\hline & & СОМт & 0.5 & & & \\
\hline & & 5-HTTLPR & 0.5 & & & \\
\hline \multirow{4}{*}{$\begin{array}{l}\text { Harm- } \\
\text { avoidance }\end{array}$} & \multirow{4}{*}{0.25} & DRD4 & 0.5 & \multirow{4}{*}{0.0625} & \multirow{4}{*}{0.015625} & \multirow{4}{*}{$21.6 \%$} \\
\hline & & DRD2 & 0.5 & & & \\
\hline & & СOMT & 0.5 & & & \\
\hline & & 5-HTTLPR & 0.5 & & & \\
\hline
\end{tabular}

Note. An equal prior priority of 0.25 (1/4) was assigned to all hypotheses because of their equal likelihood to be supported or rejected by the Bayesian analysis. Likelihood for each genetic association was determined based on a summary of existing literature (see the Appendix) on the connection between a genetic marker (e.g., DRD4) and a behavioral process (e.g., addiction).

\section{Addiction and Internet Overuse}

There has been an ongoing debate on whether Internet overuse should be categorized as an addictive disorder similar to substance and behavioral addictions. Under our hypothesis based on the addiction model, the same genetic variants (DRD4 2R and 7R, DRD2 A1) resulting in higher risk in addiction would also lead to higher risk in Internet overuse. According to the Bayesian analysis, this hypothesis was the least consistent $(0.9 \%)$ with the observed results. Beyond suggesting Internet overuse is not an addiction, this finding also disputes the way studies have been conducted on Internet overuse.

Many studies on Internet overuse consider Internet use as an uncompounded behavior regardless of the variety of online activities. This is reflected in the way we assess the severity of Internet overuse - usually by total time and frequency of Internet use, degree of positive feelings when using the Internet as well as negative feelings when Internet becomes unavailable, or repercussions on personal lives resulting from Internet overuse. These criteria are similar to how addictions are defined and diagnosed. Young (1998b) developed the first version of IAT by adopting and modifying the DSM-IV criteria for pathological gambling. However, the way users interact with the Internet is activity-dependent and can be more complex than addictive disorders. For instance, within online gaming, games from different genres manifest different potentials for overuse (M.-S. Lee et al., 2007). Therefore, it might be erroneous to look for a single explanation for the obsessions with all online activities. Future studies should treat the Internet as a platform where different online activities take place and investigate each specific activity with strong em- 
phases on their different psychological engagements and social impacts. For instance, online gambling may provide a preferable test ground for the addiction model because of its resemblance of traditional gambling and great addictiveness due to its flexibility and easy accessibility (Griffiths \& Barnes, 2008).

\section{Inattention and Internet Overuse}

Under the hypothesis based on the attention model, we expected that the attentiveness associated with DRD4 4R and 5-HTTLPR short alleles would enable their carriers to stay focused during Internet use for longer periods compared to others whose usage patterns were of shorter durations and often disrupted by their inattentiveness and hyperactivity. According to the Bayesian analysis, this hypothesis was the most consistent $(69.8 \%)$ with the observed results.

Unlike substance addictions such as tobacco addiction and alcoholism, Internet overuse is quite time-consuming and thus requires sustained attention. This is supported by the positive correlation between IAT scores and daily time spent on the Internet in our results. The attention model is further supported by additional evidence: more male participants in the DRD4 4R group spent more than three hours a day on the Internet than the $2 \mathrm{R} / 7 \mathrm{R}$ group while no such difference was found in females. Compared to females, males are more likely to play online multiplayer video games which is one of the most time-consuming and attention-requiring online activities. Compared to females, time spent on the Internet by male participants is more likely to be reduced by the presence of $2 \mathrm{R}$ or $7 \mathrm{R}$ alleles which are associated with increased inattentiveness and hyperactivity.

The attention model also circumvented the methodological problem mentioned earlier. Unlike the addiction model, it is reasonable to study Internet overuse without considering specific online activities under the attention model, because the attentiveness is essential to excessive and obsessive use of many online activities such as online gaming, shopping, and social networking. In other words, sustained attention contributes almost universally to the basis of Internet overuse regardless of the types of online activities.

Jensen et al. (1997) proposed that ADHD-related traits such as increased motor activity and hyperactivity might be beneficial under a hunter-gatherer lifestyle because of their increased effectiveness in foraging and spotting of new opportunities as well as dangers. These traits would be less maintained and selected against in a sedentary agricultural society which values sustained attention and patience (Eisenberg et al., 2008). Following this logic, frequencies of the alleles (DRD4 4R, 5-HTTLPR short) associated with increased attentiveness should be higher in populations that adopted agriculture early. East Asia (e.g., China) was one of the independent centers of origin of agriculture (Fuller, 2007). East Asian populations nowadays have the highest frequency of 5-HTTLPR short allele (Gelernter et al., 1999) and second highest frequency of DRD4 4R allele (Chang et al., 1996) in the world. This may partly explain the high rates of Internet overuse reported in this region and early official recognitions of Internet related problems in China and South Korea.

\section{Novelty-seeking, Harm-avoidance, and Internet Overuse}

Both novelty-seeking and harm-avoidance are important personality dimensions of human temperament. The Bayesian analysis showed that neither of the two models was supported strongly by the observed results. One possible explanation comes from the assumptions imbedded in the hypotheses. We assumed that the Internet was a place full of novel incentives attracting curious individuals and that the Internet offered the cautious and shy ones a safe and socially comfortable environment. The failure to support the hypotheses may simply reflect flaws in the assumptions. People spending excessive time on the Internet may be driven by factors beyond novelties, for 
example, rewards, and feelings that are less accessible in the offline world (Boyle, Connolly, \& Hainey, 2011; H. Wang \& Sun, 2011). Moreover, there has been an increase of problems associated with Internet use, such as privacy theft and cyberbullying, which greatly challenge the notion of the Internet as a risk-free world.

It is worth noting that none of the genetic associations with either novelty-seeking or harmavoidance personality was supported strongly by the previous studies. Due to a lack of metaanalysis and review studies regarding some of the relationships, it is possible that true associations were falsely neglected and the assigned conditional probabilities were unrealistic. Future studies should reexamine the two hypotheses when more information on genetic contributions to these personalities becomes available.

\section{Internet Use in College}

The present study is the first one to our knowledge that has considered average time spent on the Internet in a single session as part of its survey matrix. The majority of the participants stayed online for an average of over one hour before they went offline. This suggests that both frequency and duration of each session are important in Internet overuse among college students. In contrast, the duration of each session was not generally emphasized in studies on substance addiction and pathological gambling.

Despite the high rate of overall Internet use, frequency of use varied greatly across different online activities. On one hand, five prevalent activities, mainly ones dealing with communication and information, had frequency of use over $70 \%$. This is probably due to the popularity of social networking sites among young adults and the increasing incorporation of online teaching and learning tools in academic settings. The high frequency of use for online movies/shows watching (74\%) may reflect its role as an alternative to or a replacement of traditional TV-viewing which used to contribute to a large portion of the leisure activities among college students (Suminski, Petosa, Utter, \& Zhang, 2002). On the other hand, other online activities, mainly forms of entertainment, had frequency of use less than $40 \%$. The low frequencies of use may result from abundant options in online entertainment (Vogel, 2007) and freedom to choose according to one's interest.

\section{Gender and Internet Use}

Compared to the females, the males in the present study participated in more types of online activities on a weekly basis than the females, a likely result of their more positive attitude towards Internet use. Comparisons of frequency of use in three online activities showed significant gender differences: more males than females searched and bought songs or music online, downloaded movies/shows, and played online multiplayer video games. This is consistent with the previous findings that males were more entertainment oriented online than females. It is worth noting that the social network games revealed similar frequencies of use between genders. Unlike multiplayer online games, social network games often incorporated communication features (Wohn, Lee, Sung, \& Bjornrud, 2010), which potentially attract female users. Although we did not ask the participants about the legitimateness of their downloads, the higher likelihood of seeking illegal online materials among males reported by Fortson et al. (2007) may explain why more males downloaded movies/shows in our study. Previous studies have also reported females were more communication oriented and males were more information oriented online when using the Internet. According to our study, males and females were equally involved in activities with communicative and informational purposes. The popularity of social networking sites and the frequent use of emails and search engines for both academic and living purposes may lead to similar levels of involvement in both genders. 


\section{Conclusions}

Although we all call it the Internet, this global system of interconnected computer networks holds different meanings to different people; for some, it is a basic tool for everyday life, for others, it offers a whole other world, virtual but also real. Every user of the Internet is conducting their own experiments by exposing themselves to a multitude of online options, picking out the ones that interest them the most, and pursing them at their own pace. Whether those decisions are influenced by factors like childhood experience, family history, or social economic status is worth exploring in future studies. The findings of the present study demonstrate that the overall use of the Internet is greatly affected by one's ability to sustain attention. Carriers of the alleles associated with decreased attentiveness (DRD4 2R and 7R, 5-HTTLPR long) are protected from Internet overuse. It is worth noting that these protective alleles for Internet overuse, however, are associated with higher risk in both substance and behavioral addictions. Thus, the genotypes that predispose an individual to addiction and to Internet overuse are mutually exclusive. It is as yet unclear if this situation will persist. As more and more people access the Internet via smartphones and tablets, Internet services including mobile apps and games are increasingly designed for instant feedback and gratification. Wearable technologies such as Apple Watch and Google Glass are making technology and the Internet less obtrusive, more personal, and seamless to use. Therefore, the lure of Internet overuse may soon include apps and gadgets requiring shorter durations but at much higher frequencies. In the near future, genetic-linked inattentiveness might no longer protect users from Internet overuse. Furthermore, developers are becoming increasingly aware of the importance of neuropsychology in app/game design including defining different groups of target audience and their susceptibilities. As both the number and genres of apps/games as well as their neuropsychological pathway targets proliferate at an astonishing speed, everyone might soon be at risk for Internet overuse, despite our genotypes.

\section{References}

Aimeur, E., \& Schonfeld, D. (2011). The ultimate invasion of privacy: Identity theft. In Ninth Annual International Conference on Privacy, Security and Trust (pp. 24-31). Montreal, Canada: IEEE. http://doi.org/10.1109/PST.2011.5971959

Alavi, S. S., Maracy, M. R., Jannatifard, F., \& Eslami, M. (2011). The effect of psychiatric symptoms on the internet addiction disorder in Isfahan's University students. Journal of Research in Medical Sciences, 16(6), 793-800. Retrieved from http://www.pubmedcentral.nih.gov/articlerender.fcgi?artid=3214398\&tool=pmcentrez\&rendertype=a bstract

American Psychiatric Association. (2013). Diagnostic and Statistical Manual of Mental Disorders (5th ed.). Arlington, VA: American Psychiatric Publishing.

Asghari, V., Sanyal, S., Buchwaldt, S., Paterson, A., Jovanovic, V., \& Van Tol, H. H. (1995). Modulation of intracellular cyclic AMP levels by different human dopamine D4 receptor variants. Journal of Neurochemistry, 65(3), 1157-65.

Bai, Y.-M., Lin, C.-C., \& Chen, J.-Y. (2001). Internet Addiction Disorder Among Clients of a Virtual Clinic. Psychiatric Services, 52(10), 1397. http://doi.org/10.1176/appi.ps.52.10.1397

Bau, C. H., Roman, T., Almeida, S., \& Hutz, M. H. (1999). Dopamine D4 receptor gene and personality dimensions in Brazilian male alcoholics. Psychiatric Genetics, 9(3), 139-43.

Beard, K. W., \& Wolf, E. M. (2001). Modification in the proposed diagnostic criteria for Internet addiction. CyberPsychology \& Behavior, 4(3), 377-83.

Block, J. J. (2008). Issues for DSM-V: internet addiction. The American Journal of Psychiatry, 165(3), 306-7. http://doi.org/10.1176/appi.ajp.2007.07101556

Bobb, A. J., Castellanos, F. X., Addington, A. M., \& Rapoport, J. L. (2006). Molecular genetic studies of 
ADHD: 1991 to 2004. American Journal of Medical Genetics. Part B, Neuropsychiatric Genetics, 141B(6), 551-65. http://doi.org/10.1002/ajmg.b.30086

Boyle, E., Connolly, T. M., \& Hainey, T. (2011). The role of psychology in understanding the impact of computer games. Entertainment Computing, 2(2), 69-74.

http://doi.org/10.1016/j.entcom.2010.12.002

Burt, S. A., McGue, M., Iacono, W., Comings, D., \& MacMurray, J. (2002). An examination of the association between DRD4 and DRD2 polymorphisms and personality traits. Personality and Individual Differences, 33(6), 849-59. http://doi.org/10.1016/S0191-8869(01)00194-5

Byun, S., Ruffini, C., Mills, J. E., Douglas, A. C., Niang, M., Stepchenkova, S., ... Blanton, M. (2009). Internet addiction: metasynthesis of 1996-2006 quantitative research. CyberPsychology \& Behavior, 12(2), 203-7. http://doi.org/10.1089/cpb.2008.0102

Calati, R., Porcelli, S., Giegling, I., Hartmann, A. M., Möller, H.-J., De Ronchi, D., ... Rujescu, D. (2011). Catechol-o-methyltransferase gene modulation on suicidal behavior and personality traits: review, meta-analysis and association study. Journal of Psychiatric Research, 45(3), 309-21. http://doi.org/10.1016/j.jpsychires.2010.07.004

Campbell, A. J., Cumming, S. R., \& Hughes, I. (2006). Internet use by the socially fearful: addiction or therapy? CyberPsychology \& Behavior, 9(1), 69-81. http://doi.org/10.1089/cpb.2006.9.69

Chang, F. M., Kidd, J. R., Livak, K. J., Pakstis, A. J., \& Kidd, K. K. (1996). The world-wide distribution of allele frequencies at the human dopamine D4 receptor locus. Human Genetics, 98(1), 91-101.

Chen, C., Burton, M., Greenberger, E., \& Dmitrieva, J. (1999). Population Migration and the Variation of Dopamine D4 Receptor (DRD4) Allele Frequencies Around the Globe. Evolution and Human Behavior, 20(5), 309-24. http://doi.org/10.1016/S1090-5138(99)00015-X

Choi, K., Son, H., Park, M., Han, J., Kim, K., Lee, B., \& Gwak, H. (2009). Internet overuse and excessive daytime sleepiness in adolescents. Psychiatry and Clinical Neurosciences, 63(4), 455-62. http://doi.org/10.1111/j.1440-1819.2009.01925.x

Christakis, D. A., Moreno, M. M., Jelenchick, L., Myaing, M. T., \& Zhou, C. (2011). Problematic internet usage in US college students: a pilot study. BMC Medicine, 9(1), 77. http://doi.org/10.1186/17417015-9-77

Cloninger, C. R. (1993). A Psychobiological Model of Temperament and Character. Archives of General Psychiatry, 50(12), 975-90. http://doi.org/10.1001/archpsyc.1993.01820240059008

Comings, D. E., Ferry, L., Bradshaw-Robinson, S., Burchette, R., Chiu, C., \& Muhleman, D. (1996). The dopamine D2 receptor (DRD2) gene: a genetic risk factor in smoking. Pharmacogenetics, 6(1), 73-9. Retrieved from http://www.ncbi.nlm.nih.gov/pubmed/8845863

Comings, D. E., Gonzalez, N., Wu, S., Gade, R., Muhleman, D., Saucier, G., .. MacMurray, J. P. (1999). Studies of the $48 \mathrm{bp}$ repeat polymorphism of the DRD4 gene in impulsive, compulsive, addictive behaviors: Tourette syndrome, ADHD, pathological gambling, and substance abuse. American Journal of Medical Genetics (Neuropsychiatric Genetics), 88(4), 358-68.

Cooke, R. M. (1991). Experts in Uncertainty: Opinion and Subjective Probability in Science: Opinion and Subjective Probability in Science. Oxford University Press, USA. Retrieved from http://books.google.com/books/about/Experts_in_Uncertainty_Opinion_and_Subje.html?id=4taZBr_ nvBgC\&pgis $=1$

Cropley, V. L., Fujita, M., Innis, R. B., \& Nathan, P. J. (2006). Molecular imaging of the dopaminergic system and its association with human cognitive function. Biological Psychiatry, 59(10), 898-907. http://doi.org/10.1016/j.biopsych.2006.03.004

de Brettes, B., Berlin, I., Laurent, C., Lépine, J., Mallet, J., \& Puech, A. (1998). The dopamine D2 receptor gene TaqI A polymorphism is not associated with Novelty Seeking, Harm Avoidance and Reward Dependence in healthy subjects. European Psychiatry, 13(8), 427-30. http://doi.org/10.1016/S09249338(99)80692-0 
de Elía, R., \& Laprise, R. (2005). Diversity in interpretations of probability : Implications for weather forecasting. Monthly Weather Review, 133(5), 1129-43.

Demetrovics, Z., Varga, G., Szekely, A., Vereczkei, A., Csorba, J., Balazs, H., ... Barta, C. (2010). Association between Novelty Seeking of opiate-dependent patients and the catechol-Omethyltransferase Val(158)Met polymorphism. Comprehensive Psychiatry, 51(5), 510-5. http://doi.org/10.1016/j.comppsych.2009.11.008

Deng, G., \& Xuan, Y. (2009). Internet Addiction and Mental Health Status of Chinese College Freshmen. In The 3rd International Conference on Bioinformatics and Biomedical Engineering (pp. 1-4). Beijing, China.

Dick, D. M., \& Foroud, T. (2003). Candidate genes for alcohol dependence: a review of genetic evidence from human studies. Alcoholism: Clinical and Experimental Research, 27(5), 868-79. http://doi.org/10.1097/01.ALC.0000065436.24221.63

Ding, Y.-C., Chi, H.-C., Grady, D. L., Morishima, A., Kidd, J. R., Kidd, K. K., ... Moyzis, R. K. (2002). Evidence of positive selection acting at the human dopamine receptor D4 gene locus. Proceedings of the National Academy of Sciences of the United States of America, 99(1), 309-14. http://doi.org/10.1073/pnas.012464099

Dreber, A., Apicella, C. L., Eisenberg, D. T. A., Garcia, J. R., Zamore, R. S., Lum, J. K., \& Campbell, B. (2009). The 7R polymorphism in the dopamine receptor D4 gene (DRD4) is associated with financial risk taking in men. Evolution and Human Behavior, 30(2), 85-92. http://doi.org/10.1016/j.evolhumbehav.2008.11.001

Ducci, F., \& Goldman, D. (2012). The genetic basis of addictive disorders. The Psychiatric Clinics of North America, 35(2), 495-519. http://doi.org/10.1016/j.psc.2012.03.010

Ebstein, R. P. (2006). The molecular genetic architecture of human personality: beyond self-report questionnaires. Molecular Psychiatry, 11(5), 427-45. http://doi.org/10.1038/sj.mp.4001814

Ebstein, R. P., Gritsenko, I., Nemanov, L., Frisch, A., Osher, Y., \& Belmaker, R. H. (1997). No association between the serotonin transporter gene regulatory region polymorphism and the Tridimensional Personality Questionnaire (TPQ) temperament of harm avoidance. Molecular Psychiatry, 2(3), 224-6. http://doi.org/10.1038/sj.mp.4000275

Eisenberg, D. T. A., Campbell, B., Gray, P. B., \& Sorenson, M. D. (2008). Dopamine receptor genetic polymorphisms and body composition in undernourished pastoralists: an exploration of nutrition indices among nomadic and recently settled Ariaal men of northern Kenya. BMC Evolutionary Biology, 8(1), 173. http://doi.org/10.1186/1471-2148-8-173

Enoch, M.-A., Xu, K., Ferro, E., Harris, C. R., \& Goldman, D. (2003). Genetic origins of anxiety in women: a role for a functional catechol-O-methyltransferase polymorphism. Psychiatric Genetics, 13(1), 3341. http://doi.org/10.1097/01.ypg.0000054709.85338.c3

Faraone, S. V, Doyle, A. E., Mick, E., \& Biederman, J. (2001). Meta-analysis of the association between the 7-repeat allele of the dopamine $\mathrm{D}(4)$ receptor gene and attention deficit hyperactivity disorder. The American Journal of Psychiatry, 158(7), 1052-7.

Faraone, S. V, Perlis, R. H., Doyle, A. E., Smoller, J. W., Goralnick, J. J., Holmgren, M. A., \& Sklar, P. (2005). Molecular genetics of attention-deficit/hyperactivity disorder. Biological Psychiatry, 57(11), 1313-23. http://doi.org/10.1016/j.biopsych.2004.11.024

Feigelson, H. S., Rodriguez, C., Robertson, A. S., Jacobs, E. J., Calle, E. E., Reid, Y. A., \& Thun, M. J. (2001). Determinants of DNA yield and quality from buccal cell samples collected with mouthwash. Cancer Epidemiology, Biomarkers \& Prevention, 10(9), 1005-8.

Feng, Y., Niu, T., Xing, H., Xu, X., Chen, C., Peng, S., ... Xu, X. (2004). A common haplotype of the nicotine acetylcholine receptor alpha 4 subunit gene is associated with vulnerability to nicotine addiction in men. American Journal of Human Genetics, 75(1), 112-21. http://doi.org/10.1086/422194 
Fortson, B. L., Scotti, J. R., Chen, Y.-C., Malone, J., \& Del Ben, K. S. (2007). Internet use, abuse, and dependence among students at a southeastern regional university. Journal of American College Health, 56(2), 137-44. http://doi.org/10.3200/JACH.56.2.137-146

Fuller, D. Q. (2007). Contrasting patterns in crop domestication and domestication rates: recent archaeobotanical insights from the Old World. Annals of Botany, 100(5), 903-24. http://doi.org/10.1093/aob/mcm048

Gelernter, J., Cubells, J. F., Kidd, J. R., Pakstis, A. J., \& Kidd, K. K. (1999). Population studies of polymorphisms of the serotonin transporter protein gene. American Journal of Medical Genetics (Neuropsychiatric Genetics), 88(1), 61-6.

Gizer, I. R., Ficks, C., \& Waldman, I. D. (2009). Candidate gene studies of ADHD: a meta-analytic review. Human Genetics, 126(1), 51-90. http://doi.org/10.1007/s00439-009-0694-x

Goel, D., Subramanyam, A., \& Kamath, R. (2013). A study on the prevalence of internet addiction and its association with psychopathology in Indian adolescents. Indian Journal of Psychiatry, 55(2), 140-3. http://doi.org/10.4103/0019-5545.111451

Golimbet, V. E., Alfimova, M. V, Gritsenko, I. K., \& Ebstein, R. P. (2007). Relationship between dopamine system genes and extraversion and novelty seeking. Neuroscience and Behavioral Physiology, 37(6), 601-6. http://doi.org/10.1007/s11055-007-0058-8

Griffiths, M., \& Barnes, A. (2008). Internet Gambling: An Online Empirical Study Among Student Gamblers. International Journal of Mental Health and Addiction, 6(2), 194-204. http://doi.org/10.1007/s11469-007-9083-7

Grossman, M. H., Emanuel, B. S., \& Budarf, M. L. (1992). Chromosomal mapping of the human catecholO-methyltransferase gene to 22q11.1 $\rightarrow$ q11.2. Genomics, $12(4)$, 822-5. http://doi.org/10.1016/08887543(92)90316-K

Han, D. H., Lee, Y. S., Yang, K. C., Kim, E. Y., Lyoo, I. K., \& Renshaw, P. F. (2007). Dopamine genes and reward dependence in adolescents with excessive internet video game play. Journal of Addiction Medicine, 1(3), 133-8. http://doi.org/10.1097/ADM.0b013e31811f465f

Hashimoto, R., Noguchi, H., Hori, H., Ohi, K., Yasuda, Y., Takeda, M., \& Kunugi, H. (2007). A possible association between the Val158Met polymorphism of the catechol-O-methyl transferase gene and the personality trait of harm avoidance in Japanese healthy subjects. Neuroscience Letters, 428(1), 17-20. http://doi.org/10.1016/j.neulet.2007.09.036

Heils, A., Teufel, A., Petri, S., Stöber, G., Riederer, P., Bengel, D., \& Lesch, K. P. (1996). Allelic Variation of Human Serotonin Transporter Gene Expression. Journal of Neurochemistry, 66(6), 2621-4. http://doi.org/10.1046/j.1471-4159.1996.66062621.x

Hill, S. Y., Zezza, N., Wipprecht, G., Locke, J., \& Neiswanger, K. (1999). Personality traits and dopamine receptors (D2 and D4): linkage studies in families of alcoholics. American Journal of Medical Genetics (Neuropsychiatric Genetics), 88(6), 634-41.

Hosák, L. (2007). Role of the COMT gene Val158Met polymorphism in mental disorders: a review. European Psychiatry, 22(5), 276-81. http://doi.org/10.1016/j.eurpsy.2007.02.002

Hosák, L., Libiger, J., Cizek, J., Beránek, M., \& Cermáková, E. (2006). The COMT Val158Met polymorphism is associated with novelty seeking in Czech methamphetamine abusers: preliminary results. Neuro Endocrinology Letters, 27(6), 799-802.

Hoth, K. F., Paul, R. H., Williams, L. M., Dobson-Stone, C., Todd, E., Schofield, P. R., ... Gordon, E. (2006). Associations between the COMT Val/Met polymorphism, early life stress, and personality among healthy adults. Neuropsychiatric Disease and Treatment, 2(2), 219-25.

Jackman, S. (2009). Bayesian Analysis for the Social Sciences. John Wiley \& Sons.

Jackson, L. A., Ervin, K. S., Gardner, P. D., \& Schmitt, N. (2001). Gender and the Internet: Women Communicating and Men Searching. Sex Roles, 44(5-6), 363-379.

http://doi.org/10.1023/A:1010937901821 
Sun, Spathis, Sankaranarayanan, Chan, \& Lum

Jeffrey, R. (2004). Subjective Probability: The Real Thing. Cambridge University Press.

Jelenchick, L. A., Becker, T., \& Moreno, M. A. (2012). Assessing the psychometric properties of the Internet Addiction Test (IAT) in US college students. Psychiatry Research, 196(2-3), 296-301. http://doi.org/10.1016/j.psychres.2011.09.007

Jensen, P. S., Mrazek, D., Knapp, P. K., Steinberg, L., Pfeffer, C., Schowalter, J., \& Shapiro, T. (1997). Evolution and revolution in child psychiatry: ADHD as a disorder of adaptation. Journal of the American Academy of Child and Adolescent Psychiatry, 36(12), 1672-9. http://doi.org/10.1097/00004583-199712000-00015

Joiner, R., Gavin, J., Duffield, J., Brosnan, M., Crook, C., Durndell, A., ... Lovatt, P. (2005). Gender, Internet identification, and Internet anxiety: correlates of Internet use. CyberPsychology \& Behavior, 8(4), 371-8. http://doi.org/10.1089/cpb.2005.8.371

Jones, S., Johnson-Yale, C., Millermaier, S., \& Pérez, F. S. (2009). U.S. College Students' Internet Use: Race, Gender and Digital Divides. Journal of Computer-Mediated Communication, 14(2), 244-64. http://doi.org/10.1111/j.1083-6101.2009.01439.x

Kebir, O., \& Joober, R. (2011). Neuropsychological endophenotypes in attention-deficit/hyperactivity disorder: a review of genetic association studies. European Archives of Psychiatry and Clinical Neuroscience, 261(8), 583-94. http://doi.org/10.1007/s00406-011-0207-5

Kent, L., Doerry, U., Hardy, E., Parmar, R., Gingell, K., Hawi, Z., ... Craddock, N. (2002). Evidence that variation at the serotonin transporter gene influences susceptibility to attention deficit hyperactivity disorder (ADHD): analysis and pooled analysis. Molecular Psychiatry, 7(8), 908-12. http://doi.org/10.1038/sj.mp.4001100

Khan, S. A., \& Faraone, S. V. (2006). The genetics of ADHD: A literature review of 2005. Current Psychiatry Reports, 8(5), 393-7. http://doi.org/10.1007/s11920-006-0042-y

Kim, S. J., Kim, Y. S., Kim, S. Y., Lee, H. S., \& Kim, C.-H. (2006). An association study of catechol-Omethyltransferase and monoamine oxidase A polymorphisms and personality traits in Koreans. Neuroscience Letters, 401(1-2), 154-8. http://doi.org/10.1016/j.neulet.2006.03.006

Kluger, A. N., Siegfried, Z., \& Ebstein, R. P. (2002). A meta-analysis of the association between DRD4 polymorphism and novelty seeking. Molecular Psychiatry, 7(7), 712-7. http://doi.org/10.1038/sj.mp.4001082

Ko, C. H., Yen, J. Y., Yen, C. F., Chen, C. S., \& Chen, C. C. (2008). The association between Internet addiction and psychiatric disorder: a review of the literature. European Psychiatry, 27(1), 1-8. http://doi.org/10.1016/j.eurpsy.2010.04.011

Köhnke, M. D. (2008). Approach to the genetics of alcoholism: a review based on pathophysiology. Biochemical Pharmacology, 75(1), 160-77. http://doi.org/10.1016/j.bcp.2007.06.021

Kose, S. (2003). A Psychobiological Model of Temperament and Character: TCI. Yeni Symposium, 41(2), $86-97$.

Kreek, M. J., Nielsen, D. A., Butelman, E. R., \& LaForge, K. S. (2005). Genetic influences on impulsivity, risk taking, stress responsivity and vulnerability to drug abuse and addiction. Nature Neuroscience, 8(11), 1450-7. http://doi.org/10.1038/nn1583

Kuhnen, C. M., \& Chiao, J. Y. (2009). Genetic determinants of financial risk taking. PLoS One, 4(2), e4362. http://doi.org/10.1371/journal.pone.0004362

Lachman, H. M., Papolos, D. F., Saito, T., Yu, Y. M., Szumlanski, C. L., \& Weinshilboum, R. M. (1996). Human catechol-O-methyltransferase pharmacogenetics: description of a functional polymorphism and its potential application to neuropsychiatric disorders. Pharmacogenetics, 6(3), 243-50. Retrieved from http://www.ncbi.nlm.nih.gov/pubmed/8807664

Lam, L. T., Peng, Z., Mai, J., \& Jing, J. (2009). Factors associated with Internet addiction among adolescents. CyberPsychology \& Behavior, 12(5), 551-5. http://doi.org/10.1089/cpb.2009.0036 
Le Foll, B., Gallo, A., Le Strat, Y., Lu, L., \& Gorwood, P. (2009). Genetics of dopamine receptors and drug addiction: a comprehensive review. Behavioural Pharmacology, 20(1), 1-17. http://doi.org/10.1097/FBP.0b013e3283242f05

Lee, M.-S., Ko, Y.-H., Song, H.-S., Kwon, K.-H., Lee, H.-S., Nam, M., \& Jung, I.-K. (2007). Characteristics of Internet use in relation to game genre in Korean adolescents. Cyberpsychology \& Behavior, 10(2), 278-85. http://doi.org/10.1089/cpb.2006.9958

Lee, S. H., Ham, B.-J., Cho, Y.-H., Lee, S.-M., \& Shim, S. H. (2007). Association study of dopamine receptor D2 TaqI A polymorphism and reward-related personality traits in healthy Korean young females. Neuropsychobiology, 56(2-3), 146-51. http://doi.org/10.1159/000115781

Lee, Y. S., Han, D. H., Yang, K. C., Daniels, M. a, Na, C., Kee, B. S., \& Renshaw, P. F. (2008). Depression like characteristics of 5HTTLPR polymorphism and temperament in excessive internet users. Journal of Affective Disorders, 109(1-2), 165-9. http://doi.org/10.1016/j.jad.2007.10.020

Leung, P. W. L., Lee, C. C., Hung, S. F., Ho, T. P., Tang, C. P., Kwong, S. L., ... Swanson, J. (2005). Dopamine receptor D4 (DRD4) gene in Han Chinese children with attention-deficit/hyperactivity disorder (ADHD): increased prevalence of the 2-repeat allele. American Journal of Medical Genetics. Part B, Neuropsychiatric Genetics, 133B(1), 54-6. http://doi.org/10.1002/ajmg.b.30129

Li, D., Sham, P. C., Owen, M. J., \& He, L. (2006). Meta-analysis shows significant association between dopamine system genes and attention deficit hyperactivity disorder (ADHD). Human Molecular Genetics, 15(14), 2276-84. http://doi.org/10.1093/hmg/ddl152

Li, M. D., \& Burmeister, M. (2009). New insights into the genetics of addiction. Nature Reviews. Genetics, 10(4), 225-31. http://doi.org/10.1038/nrg2536

Lichtenberg, P., Bachner-Melman, R., Ebstein, R. P., \& Crawford, H. J. (2004). Hypnotic susceptibility: multidimensional relationships with Cloninger's Tridimensional Personality Questionnaire, COMT polymorphisms, absorption, and attentional characteristics. The International Journal of Clinical and Experimental Hypnosis, 52(1), 47-72. http://doi.org/10.1076/iceh.52.1.47.23922

Light, K. J., Joyce, P. R., Luty, S. E., Mulder, R. T., Carter, J. D., Frampton, C. M. A., ... Kennedy, M. A. (2007). An association study of DRD2 and COMT polymorphisms with novelty seeking and harm avoidance scores, in two independent samples of depressed patients. Behavioral and Brain Functions, 3(3). http://doi.org/10.1186/1744-9081-3-3

Lin, M.-P., Ko, H.-C., \& Wu, J. Y.-W. (2011). Prevalence and psychosocial risk factors associated with internet addiction in a nationally representative sample of college students in Taiwan. Cyberpsychology, Behavior and Social Networking, 14(12), 741-6. http://doi.org/10.1089/cyber.2010.0574

Markett, S., Montag, C., \& Reuter, M. (2011). The nicotinic acetylcholine receptor gene CHRNA4 is associated with negative emotionality. Emotion, 11(2), 450-5. http://doi.org/10.1037/a0021784

McGeary, J. (2009). The DRD4 exon 3 VNTR polymorphism and addiction-related phenotypes: a review. Pharmacology, Biochemistry and Behavior, 93(3), 222-9. http://doi.org/10.1016/j.pbb.2009.03.010

Mitchell, P. (2000). Internet addiction: genuine diagnosis or not? Lancet, 355(9204), 632. http://doi.org/10.1016/S0140-6736(05)72500-9

Montag, C., Kirsch, P., Sauer, C., Psych, D., Markett, S., \& Reuter, M. (2012). The Role of the CHRNA4 Gene in Internet Addiction. Journal of Addiction Medicine, 6(3), 191-5. http://doi.org/10.1097/ADM.0b013e31825ba7e7

Morahan-Martin, J., \& Schumacher, P. (2000). Incidence and correlates of pathological Internet use among college students. Computers in Human Behavior, 16(1), 13-29. http://doi.org/10.1016/S07475632(99)00049-7

Munafò, M. R., Clark, T. G., Moore, L. R., Payne, E., Walton, R., \& Flint, J. (2003). Genetic polymorphisms and personality in healthy adults: a systematic review and meta-analysis. Molecular Psychiatry, 8(5), 471-84. http://doi.org/10.1038/sj.mp.4001326 
Munafò, M. R., Freimer, N. B., Ng, W., Ophoff, R., Veijola, J., Miettunen, J., ... Flint, J. (2009). 5HTTLPR genotype and anxiety-related personality traits: a meta-analysis and new data. American Journal of Medical Genetics. Part B, Neuropsychiatric Genetics, 150B(2), 271-81. http://doi.org/10.1002/ajmg.b.30808

Muñoz-Rivas, M. J., Fernández, L., \& Gámez-Guadix, M. (2010). Analysis of the indicators of pathological Internet use in Spanish university students. The Spanish Journal of Psychology, 13(2), 697-707.

Murali, V., \& George, S. (2007). Lost online: an overview of internet addiction. Advances in Psychiatric Treatment, 13(1), 24-30. http://doi.org/10.1192/apt.bp.106.002907

Nakamura, M., Ueno, S., Sano, A., \& Tanabe, H. (2000). The human serotonin transporter gene linked polymorphism (5-HTTLPR) shows ten novel allelic variants. Molecular Psychiatry, 5(1), 32-8. http://doi.org/10.1038/sj.mp.4000698

Ni, X., Yan, H., Chen, S., \& Liu, Z. (2009). Factors influencing internet addiction in a sample of freshmen university students in China. CyberPsychology \& Behavior, 12(3), 327-30. http://doi.org/10.1089/cpb.2008.0321

Niculović, M., Živković, D., Manasijević, D., \& Štrbac, N. (2012). Monitoring the effect of Internet use on students behavior case study: Technical Faculty Bor, University of Belgrade. Educational Technology Research and Development, 60(3), 547-59. http://doi.org/10.1007/s11423-012-9238-5

Noble, E. P. (2000). Addiction and its reward process through polymorphisms of the D2 dopamine receptor gene: a review. European Psychiatry, 15(2), 79-89. http://doi.org/10.1016/S0924-9338(00)00208-X

Noble, E. P. (2003). D2 dopamine receptor gene in psychiatric and neurologic disorders and its phenotypes. American Journal of Medical Genetics. Part B, Neuropsychiatric Genetics, 116B(1), 103-25. http://doi.org/10.1002/ajmg.b.10005

Odell, P. M., Korgen, K. O., Schumacher, P., \& Delucchi, M. (2000). Internet Use Among Female and Male College Students. CyberPsychology \& Behavior, 3(5), 855-62. http://doi.org/10.1089/10949310050191836

Ogino, S., \& Wilson, R. B. (2004). Bayesian analysis and risk assessment in genetic counseling and testing. The Journal of Molecular Diagnostics, 6(1), 1-9. http://doi.org/10.1016/S1525-1578(10)60484-9

Park, S. K., Kim, J. Y., \& Cho, C. B. (2008). Prevalence of Internet addiction and correlations with family factors among South Korean adolescents. Adolescence, 43(172), 895-909.

Pempek, T. A., Yermolayeva, Y. A., \& Calvert, S. L. (2009). College students' social networking experiences on Facebook. Journal of Applied Developmental Psychology, 30(3), 227-38. http://doi.org/10.1016/j.appdev.2008.12.010

Pohjalainen, T., Rinne, J. O., Någren, K., Lehikoinen, P., Anttila, K., Syvälahti, E. K., \& Hietala, J. (1998). The A1 allele of the human D2 dopamine receptor gene predicts low D2 receptor availability in healthy volunteers. Molecular Psychiatry, 3(3), 256-60. Retrieved from http://www.ncbi.nlm.nih.gov/pubmed/9672901

Reuter, M., \& Hennig, J. (2005). Association of the functional catechol-O-methyltransferase VAL158MET polymorphism with the personality trait of extraversion. NeuroReport, 16(10), 1135-8.

Ricketts, M. H., Hamer, R. M., Sage, J. I., Manowitz, P., Feng, F., \& Menza, M. A. (1998). Association of a serotonin transporter gene promoter polymorphism with harm avoidance behaviour in an elderly population. Psychiatric Genetics, 8(2), 41-4.

Rotunda, R. J., Kass, S. J., Sutton, M. A., \& Leon, D. T. (2003). Internet use and misuse. Preliminary findings from a new assessment instrument. Behavior Modification, 27(4), 484-504.

Rubinstein, M., Cepeda, C., Hurst, R. S., Flores-Hernandez, J., Ariano, M. A., Falzone, T. L., ... Grandy, D. K. (2001). Dopamine D4 receptor-deficient mice display cortical hyperexcitability. The Journal of Neuroscience, 21(11), 3756-63. 
Samochowiec, J., Rybakowski, F., Czerski, P., Zakrzewska, M., Stepień, G., Pełka-Wysiecka, J., ... Hauser, J. (2001). Polymorphisms in the dopamine, serotonin, and norepinephrine transporter genes and their relationship to temperamental dimensions measured by the Temperament and Character Inventory in healthy volunteers. Neuropsychobiology, 43(4), 248-53. http://doi.org/54898

Saville, B. K., Gisbert, A., Kopp, J., \& Telesco, C. (2009). Internet Addiction and Delay Discounting in College Students. Psychological Record, 60(2), 273-86.

Schinka, J. A., Busch, R. M., \& Robichaux-Keene, N. (2004). A meta-analysis of the association between the serotonin transporter gene polymorphism (5-HTTLPR) and trait anxiety. Molecular Psychiatry, 9(2), 197-202. http://doi.org/10.1038/sj.mp.4001405

Schinka, J. A., Letsch, E. A., \& Crawford, F. C. (2002). DRD4 and novelty seeking: results of metaanalyses. American Journal of Medical Genetics (Neuropsychiatric Genetics), 114(6), 643-8. http://doi.org/10.1002/ajmg.10649

Schweitzer, J. B., Cummins, T. K., \& Kant, C. A. (2001). Attention-deficit/hyperactivity disorder. The Medical Clinics of North America, 85(3), 757-77.

Sen, S., Burmeister, M., \& Ghosh, D. (2004). Meta-analysis of the association between a serotonin transporter promoter polymorphism (5-HTTLPR) and anxiety-related personality traits. American Journal of Medical Genetics. Part B, Neuropsychiatric Genetics, 127B(1), 85-9. http://doi.org/10.1002/ajmg.b.20158

Serretti, A., Calati, R., Mandelli, L., \& De Ronchi, D. (2006). Serotonin Transporter Gene Variants and Behavior: A Comprehensive Review. Current Drug Targets, 7(12), 1659-69. http://doi.org/10.2174/138945006779025419

Serretti, A., Mandelli, L., Lorenzi, C., Landoni, S., Calati, R., Insacco, C., \& Cloninger, C. R. (2006). Temperament and character in mood disorders: influence of DRD4, SERTPR, TPH and MAO-A polymorphisms. Neuropsychobiology, 53(1), 9-16. http://doi.org/10.1159/000089916

Sherman, R. C., End, C., Kraan, E., Cole, A., Campbell, J., Birchmeier, Z., \& Klausner, J. (2000). The Internet Gender Gap Among College Students: Forgotten But Not Gone? CyberPsychology \& Behavior, 3(5), 885-94. http://doi.org/10.1089/10949310050191854

Siu, N. O., \& Kelly, D. L. (1998). Bayesian parameter estimation in probabilistic risk assessment. Reliability Engineering \& System Safety, 62(1-2), 89-116. http://doi.org/10.1016/S09518320(97)00159-2

Slate, J. R., Manuel, M., \& Brinson, K. H. J. (2002). The "Digital Divide": Hispanic college students' views of educational uses of the Internet. Assessment \& Evaluation in Higher Education, 27(1), 7593. http://doi.org/10.1080/02602930120105081

Smolka, M. N., Schumann, G., Wrase, J., Grüsser, S. M., Flor, H., Mann, K., ... Heinz, A. (2005). Catechol-O-methyltransferase val158met genotype affects processing of emotional stimuli in the amygdala and prefrontal cortex. The Journal of Neuroscience, 25(4), 836-42. http://doi.org/10.1523/JNEUROSCI.1792-04.2005

Spiegelhalter, D. J., Franklin, R. C., \& Bull, K. (2013). Assessment, Criticism and Improvement of Imprecise Subjective Probabilities for a Medical Expert System. Eprint arXiv:1304.1529, 335-342.

Stephens, M., \& Balding, D. J. (2009). Bayesian statistical methods for genetic association studies. Nature Reviews. Genetics, 10(10), 681-90. http://doi.org/10.1038/nrg2615

Suminski, R. R., Petosa, R., Utter, A. C., \& Zhang, J. J. (2002). Physical activity among ethnically diverse college students. Journal of American College Health, 51(2), 75-80. http://doi.org/10.1080/07448480209596333

Suzuki, A., Matsumoto, Y., Oshino, S., Kamata, M., Goto, K., \& Otani, K. (2008). Combination of the serotonin transporter and norepinephrine transporter gene promoter polymorphisms might influence harm avoidance and novelty seeking in healthy females. Neuroscience Letters, 439(1), 52-5. http://doi.org/10.1016/j.neulet.2008.04.088 
Sun, Spathis, Sankaranarayanan, Chan, \& Lum

Tammimäki, A. E., \& Männistö, P. T. (2010). Are genetic variants of COMT associated with addiction? Pharmacogenetics and Genomics, 20(12), 717-41. http://doi.org/10.1097/FPC.0b013e328340bdf2

Tokunaga, R. S. (2010). Following you home from school: A critical review and synthesis of research on cyberbullying victimization. Computers in Human Behavior, 26(3), 277-87. http://doi.org/10.1016/j.chb.2009.11.014

Tsai, H. F., Cheng, S. H., Yeh, T. L., Shih, C.-C., Chen, K. C., Yang, Y. C., \& Yang, Y. K. (2009). The risk factors of Internet addiction - a survey of university freshmen. Psychiatry Research, 167(3), 294-9. http://doi.org/10.1016/j.psychres.2008.01.015

Tsai, S.-J., Hong, C.-J., Yu, Y. W.-Y., \& Chen, T.-J. (2004). Association study of catechol-Omethyltransferase gene and dopamine D4 receptor gene polymorphisms and personality traits in healthy young Chinese females. Neuropsychobiology, 50(2), 153-6. http://doi.org/10.1159/000079107

Tsuchimine, S., Yasui-Furukori, N., Sasaki, K., Kaneda, A., Sugawara, N., Yoshida, S., \& Kaneko, S. (2012). Association between the dopamine D2 receptor (DRD2) polymorphism and the personality traits of healthy Japanese participants. Progress in Neuro-Psychopharmacology \& Biological Psychiatry, 38(2), 190-3. http://doi.org/10.1016/j.pnpbp.2012.03.008

Tufekci, Z. (2008). Grooming, Gossip, Facebook and Myspace. Information, Communication \& Society, 11(4), 544-64. http://doi.org/10.1080/13691180801999050

Van Gestel, S., Forsgren, T., Claes, S., Del-Favero, J., Van Duijn, C. M., Sluijs, S., ... Van Broeckhoven, C. (2002). Epistatic effect of genes from the dopamine and serotonin systems on the temperament traits of novelty seeking and harm avoidance. Molecular Psychiatry, 7(5), 448-50. http://doi.org/10.1038/sj.mp.4001005

Van Tol, H. H., Wu, C. M., Guan, H. C., Ohara, K., Bunzow, J. R., Civelli, O., ... Jovanovic, V. (1992). Multiple dopamine D4 receptor variants in the human population. Nature, 358(6382), 149-52. http://doi.org/10.1038/358149a0

Verdejo-García, A., Lawrence, A. J., \& Clark, L. (2008). Impulsivity as a vulnerability marker for substance-use disorders: review of findings from high-risk research, problem gamblers and genetic association studies. Neuroscience and Biobehavioral Reviews, 32(4), 777-810. http://doi.org/10.1016/j.neubiorev.2007.11.003

Vick, S. G. (2002). Degrees of Belief: Subjective Probability and Engineering Judgment. Reston, VA: Amer Society of Civil Engineers Press.

Vogel, H. L. (2007). Entertainment Industry Economics: A Guide for Financial Analysis (7th Editio). Cambridge University Press.

Wacholder, S., Chanock, S., Garcia-Closas, M., El Ghormli, L., \& Rothman, N. (2004). Assessing the probability that a positive report is false: an approach for molecular epidemiology studies. Journal of the National Cancer Institute, 96(6), 434-42.

Wang, E., Ding, Y.-C., Flodman, P., Kidd, J. R., Kidd, K. K., Grady, D. L., ... Moyzis, R. K. (2004). The genetic architecture of selection at the human dopamine receptor D4 (DRD4) gene locus. American Journal of Human Genetics, 74(5), 931-44. http://doi.org/10.1086/420854

Wang, H., \& Sun, C. (2011). Game Reward Systems: Gaming Experiences and Social Meanings. In Think Design Play: The fifth international conference of the Digital Research Association.

Wang, W. (2001). Internet dependency and psychosocial maturity among college students. International Journal of Human-Computer Studies, 55(6), 919-38. http://doi.org/10.1006/ijhc.2001.0510

Weinstein, A., \& Lejoyeux, M. (2010). Internet addiction or excessive internet use. The American Journal of Drug and Alcohol Abuse, 36(5), 254-260. http://doi.org/10.3109/00952990.2010.503823

Whalen, C. K., \& Henker, B. (1998). Attention-deficit/hyperactivity disorders. In T. H. Ollendick \& M. Hersen (Eds.), Handbook of Child Psychopathology (3rd ed., pp. 181-211). New York: Plenum Press. 
Wohn, D. Y., Lee, Y., Sung, J., \& Bjornrud, T. (2010). Building common ground and reciprocity through social network games. In Proceedings of ACM Conference on Human Factors in Computing Systems (pp. 4423-8). Atlanta, GA. http://doi.org/10.1145/1753846.1754164

Wu, J., Xiao, H., Sun, H., Zou, L., \& Zhu, L.-Q. (2012). Role of dopamine receptors in ADHD: a systematic meta-analysis. Molecular Neurobiology, 45(3), 605-20. http://doi.org/10.1007/s12035012-8278-5

Yen, J.-Y., Yen, C.-F., Chen, C.-S., Tang, T.-C., \& Ko, C.-H. (2009). The association between adult ADHD symptoms and internet addiction among college students: the gender difference. CyberPsychology \& Behavior, 12(2), 187-91. http://doi.org/10.1089/cpb.2008.0113

Young, K. S. (1996). Psychology of computer use: XL. Addictive use of the Internet: a case that breaks the stereotype. Psychological Reports, 79(3 Pt 1), 899-902. http://doi.org/10.2466/pr0.1996.79.3.899

Young, K. S. (1998a). Caught in the Net: How to Recognize the Signs of Internet Addiction--and a Winning Strategy for Recovery. John Wiley \& Sons.

Young, K. S. (1998b). Internet Addiction: The Emergence of a New Clinical Disorder. CyberPsychology \& Behavior, 1(3), 237-44. http://doi.org/10.1089/cpb.1998.1.237

Young, K. S. (2004). Internet Addiction: A New Clinical Phenomenon and Its Consequences. American Behavioral Scientist, 48(4), 402-415. http://doi.org/10.1177/0002764204270278

Zhang, Y. (2002). Comparison of internet attitudes between industrial employees and college students. CyberPsychology \& Behavior, 5(2), 143-9. 


\section{Appendix \\ Supplementary Material \#1: Internet Addiction Test (IAT) developed by Kimberly Young (1998)}

\section{Please answer the following questions using this scale:}

\section{a. Rarely b. Occasionally c. Frequently d. Often e. Always f. Does Not Apply}

1. How often do you find that you stay on-line or play longer than you intended?

2. How often do you neglect household chores to spend more time on-line?

3. How often do you prefer the excitement of the Internet to intimacy with your partner?

4. How often do you form new relationships with fellow on-line users?

5. How often do others in your life complain to you about the amount of time you spend on-line?

6. How often do your grades or school work suffer because of the amount of time you spend on-line?

7. How often do you check your e-mail before something else that you need to do?

8. How often does your job performance or productivity suffer because of the Internet?

9. How often do you become defensive or secretive when anyone asks you what you do on-line?

10. How often do you block out disturbing thoughts about your life with soothing thoughts of the Internet?

11. How often do you find yourself anticipating when you will go on-line again?

12. How often do you fear that life without the Internet would be boring, empty, and joyless?

13. How often do you snap, yell, or act annoyed if someone bothers you while you are on-line?

14. How often do you lose sleep due to late-night log-ins?

15. How often do you feel preoccupied with the Internet when off-line, or fantasize about being on-line?

16. How often do you find yourself saying "just a few more minutes" when on-line?

17. How often do you try to cut down the amount of time you spend on-line and fail?

18. How often do you try to hide how long you've been on-line?

19. How often do you choose to spend more time on-line over going out with others?

20. How often do you feel depressed, moody or nervous when you are off-line, which goes away once you are back on-line? 


\section{Supplementary Material \#2: Additional information on studies reviewed and determination of the likelihood for each association.}

\begin{tabular}{|c|c|c|c|c|}
\hline $\begin{array}{l}\text { Hy- } \\
\text { poth- } \\
\text { esis }\end{array}$ & Studies reviewed & Summary of the studies reviewed & $\begin{array}{l}\text { Observed results } \\
\text { in our study }\end{array}$ & $\begin{array}{l}\text { Likelihood } \\
\text { for each } \\
\text { associa- } \\
\text { tion }\end{array}$ \\
\hline \multirow{4}{*}{$\begin{array}{l}\text { Addic- } \\
\text { tion }\end{array}$} & $\begin{array}{l}\text { Comings et al. 1999; } \\
\text { McGeary 2009+; } \\
\text { Le Foll et al. 2009+. }\end{array}$ & $\begin{array}{l}\text { Studies revealed strong evidence that } \\
\text { DRD4 } 2 R \text { and } 7 R \text { were associated with } \\
\text { higher risks for addiction compared to } 4 R \text {. }\end{array}$ & $\begin{array}{l}\text { DRD4: 4R allele } \\
\text { was associated } \\
\text { with Internet over- } \\
\text { use }\end{array}$ & 0.1 \\
\hline & 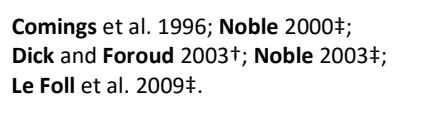 & $\begin{array}{l}\text { Studies revealed strong evidence that } \\
\text { DRD2 A1 was associated with higher risks } \\
\text { for addiction compared to } A 2 \text {. }\end{array}$ & $\begin{array}{l}\text { DRD2: not associ- } \\
\text { ated with Internet } \\
\text { overuse }\end{array}$ & 0.1 \\
\hline & $\begin{array}{l}\text { Vandenbergh et al. 1997; Kreek et al. } \\
\text { 2005+; } \\
\text { Hosák 2007†; Köhnke 2008†; } \\
\text { Tammimäki \& Männistö 2010‡; Ducci \& } \\
\text { Goldman 2012†. }\end{array}$ & $\begin{array}{l}\text { Results of the studies were mixed and } \\
\text { inconsistent: each of the alleles was asso- } \\
\text { ciated with addiction; some studies failed } \\
\text { to detect any associations. }\end{array}$ & $\begin{array}{l}\text { COMT: not associ- } \\
\text { ated with Internet } \\
\text { overuse }\end{array}$ & $0.5^{*}$ \\
\hline & $\begin{array}{l}\text { Dick and Foroud 2003+; Feinn et al. } \\
\text { 2005‡; Serretti et al. 2006+; } \\
\text { Bleich et al. 2007; Köhnke 2008+; } \\
\text { Verdejo-García et al. 2008+; } \\
\text { van der Zwaluw et al. 2010; Merenäkk } \\
\text { et al. } 2011 .\end{array}$ & $\begin{array}{l}\text { Most studies focused on alcoholism. In } \\
\text { general, results were mixed and incon- } \\
\text { sistent: each of the alleles was associated } \\
\text { with higher risks for addiction; some stud- } \\
\text { ies failed to detect any associations. }\end{array}$ & $\begin{array}{l}\text { 5-HTTLPR: short } \\
\text { allele was associat- } \\
\text { ed with Internet } \\
\text { overuse only in } \\
\text { males }\end{array}$ & $0.5^{*}$ \\
\hline \multirow{4}{*}{$\begin{array}{l}\text { ADHD } \\
\text { (inat- } \\
\text { ten- } \\
\text { tion) }\end{array}$} & 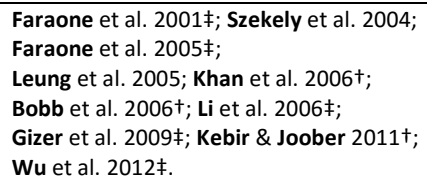 & $\begin{array}{l}\text { Studies revealed strong evidence that } \\
\text { DRD4 } 2 R \text { and } 7 R \text { were associated with } \\
\text { inattention and higher risks for ADHD } \\
\text { compared to } 4 R \text {. }\end{array}$ & $\begin{array}{l}\text { DRD4: } 4 \text { R allele } \\
\text { was associated } \\
\text { with Internet over- } \\
\text { use }\end{array}$ & 0.9 \\
\hline & 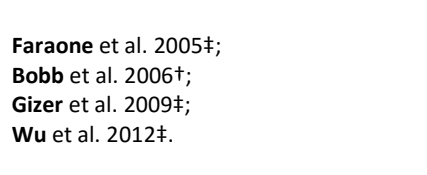 & $\begin{array}{l}\text { Results of the studies were mixed and } \\
\text { inconsistent: each of the alleles was asso- } \\
\text { ciated with higher risks for ADHD; meta- } \\
\text { analyses failed to draw definitive conclu- } \\
\text { sions. }\end{array}$ & $\begin{array}{l}\text { DRD2: not associ- } \\
\text { ated with Internet } \\
\text { overuse }\end{array}$ & $0.5^{*}$ \\
\hline & 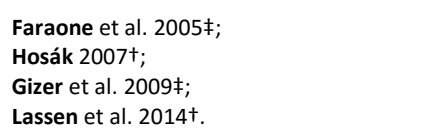 & $\begin{array}{l}\text { Studies revealed strong evidence that } \\
\text { there was no association between COMT } \\
\text { Val158Met polymorphism and risks for } \\
\text { ADHD. }\end{array}$ & $\begin{array}{l}\text { COMT: not associ- } \\
\text { ated with Internet } \\
\text { overuse }\end{array}$ & 0.9 \\
\hline & 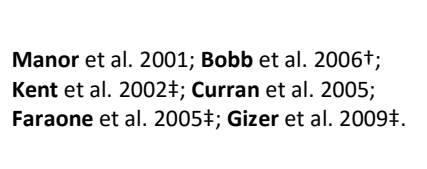 & $\begin{array}{l}\text { Studies revealed strong evidence that } \\
\text { 5HTTLPR long allele was associated with } \\
\text { ADHD compared to the short allele. }\end{array}$ & $\begin{array}{l}\text { 5-HTTLPR: short } \\
\text { allele was associat- } \\
\text { ed with Internet } \\
\text { overuse only in } \\
\text { males }\end{array}$ & $0.5^{*}$ \\
\hline
\end{tabular}

Ebstein et al. 1996; Noble et al. 1998; Bau et al. 1999; Hill et al. 1999; Tomitaka et al. 1999; Lusher et al. 2001+; Kluger et al. 2002 ;

Schinka et al. 2002 ; Burt et al. 2002; Savitz et al. 2004†;

Szekely et al. 2004; Tsai et al. 2004; Kreek et al. 2005†; Ebstein 2006t.

Noble et al. 1998; de Brettes et al. 1998;

Novel- Hill et al. 1999;

ty- $\quad$ Burt et al. 2002; Munafò et al. 2003‡;

seeking Light et al. 2007;

seeking Lee et al. 2007; Kazantseva et al. 2011; Tsuchimine et al. 2012.

Lichtenberg et al. 2004; Tsai et al. 2004; Reuter \& Hennig 2005;

Hoth et al. 2006 Hosák et al. 2006; Kim et al. 2006;

Golimbet et al. 2007; Hashimoto et al. 2007; Light et al. 2007;

Demetrovics et al. 2010; Calati et al.

2011 t.
Although several studies linked DRD4 7R to novelty-seeking, strong evidence emerged from reviews and meta-analyses that DRD4 exon 3 VNTR polymorphism was not associated with novelty-seeking.

Although few studies linked DRD2 A1 to novelty-seeking, strong evidence emerged from other studies including a metaanalysis that DRD2 Taq1A polymorphism was not associated with novelty-seeking.

Results of the studies were mixed and inconsistent: each of the alleles was associated with novelty-seeking; a few studies failed to find any associations.
DRD4: 4R allele was associated with Internet overuse

DRD2: not associated with Internet overuse

COMT: not associated with Internet overuse
$0.5^{*}$ 
Ebstein et al. 1997; Ricketts et al. 1998; Samochowiec et al. 2001; Van Gestel et al. 2002;

Munafò et al. 2003‡; Suzuki et al. 2008.

Bau et al. 1999; Hill et al. 1999; Munafò et al. 2003‡;

Szekely et al. 2004; Tsai et al. 2004; Serretti et al. 2006;

Dreber et al. 2009; Kuhnen \& Chiao 2009.

de Brettes et al. 1998; Hill et al. 1999; Munafò et al. 2003‡; Lee et al. 2007; Light et al. 2007; Tsuchimine et al. 2012.

Harm-

avoid- Enoch et al. 2003; Lichtenberg et al.

ance

2004; Tsai et al. 2004;

Smolka et al. 2005; Kim et al. 2006

Golimbet et al. 2007;

Hashimoto et al. 2007; Light et al. 2007;

Calati et al. 2011†.

Ebstein et al. 1997; Ricketts et al. 1998;

Osher et al. 2000;

Samochowiec et al. 2001; Van Gestel et

al. 2002; Munafò et al. 2003‡;

Sen et al. 2004¥; Schinka et al. 2004¥;

Szekely et al. 2004;

Ebstein 2006t; Kuhnen and Chiao 2009; Munafò et al. 2009ł.
Studies revealed strong evidence that 5HTTLPR polymorphism was not associated with novelty-seeking.

Results of the studies were mixed and inconsistent: early studies linked DRD4 4R with harm-avoidance, while recent studies linked 7R with financial risk taking. One meta-analysis study failed to detect any associations.

Results of the studies were mixed: although one meta-analysis found association between DRD2 Taq1A polymorphism and harm-avoidance trait, many later studies failed to detect any associations.

Results of the studies were mixed and inconsistent: each of the alleles was associated with harm-avoidance; some studies failed to find any associations.

Studies revealed strong evidence that there was no association between 5HTTLPR length polymorphism and harmavoidance.
5-HTTLPR: short

allele was associated with Internet overuse only in

males

DRD4: 4R allele was associated with Internet overuse

DRD2: not associated with Internet overuse

COMT: not associated with Internet overuse

5-HTTLPR: short allele was associated with Internet overuse only in males

† Review studies

¥ Meta-analyses

* A likelihood of 0.5 was assigned when 1) previous studies revealed mixed and inconsistent findings regarding the relationship between the gene and the behavioral process; 2) significant results were only observed in one gender but not the other or in the overall population (i.e. 5HTTLPR length polymorphism)

\section{Biographies}

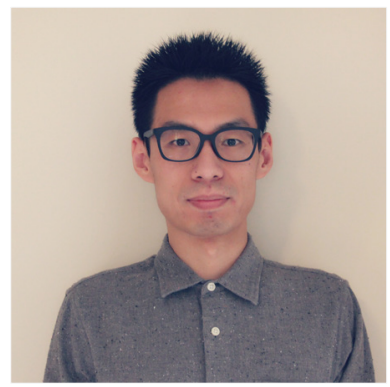

Cheng Sun is a postdoctoral researcher at Duke Kunshan University (China). He recently graduated with a $\mathrm{PhD}$ in Anthropology from the State University of New York at Binghamton. His graduate research focused on technology adoption and its relationships with human health in developing countries (e.g., obesogenic effects of use of consumer electronics) and in developed countries (Internet addiction among college students).

His current work focuses on the use of mobile applications and text messages as an efficient way to improve secondary prevention and rehabilitation of stroke patients in rural China.

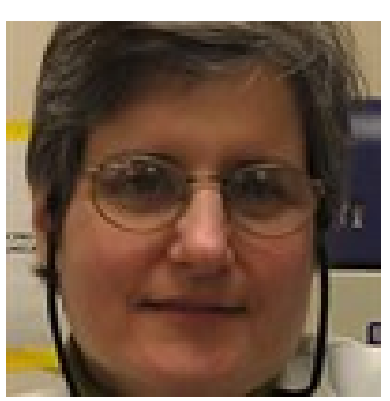

Rita Spathis is a Laboratory Manager in the Department of Anthropology at Binghamton University (NY, USA). She received her BS in Biochemistry from the State University of New York at Stonybrook and her MS in Biomedical Anthropology from Binghamton University. 


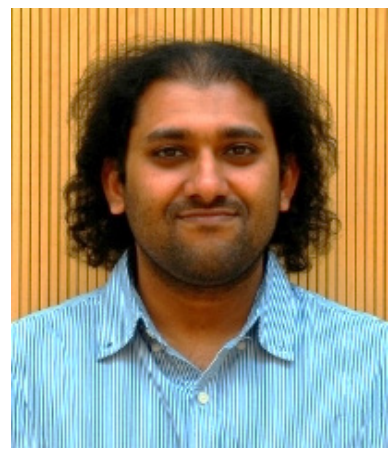

Krithivasan Sankaranarayanan is currently a Research Assistant Professor at the Department of Anthropology at the University of Oklahoma. His research interests are primarily in the fields of microbial ecology, evolution and human-microbial interactions, within the context of human health and disease. He is also involved in ancient DNA research focused on evolution of the human microbiome, and longterm evolution of microbial life in hypersaline environments.

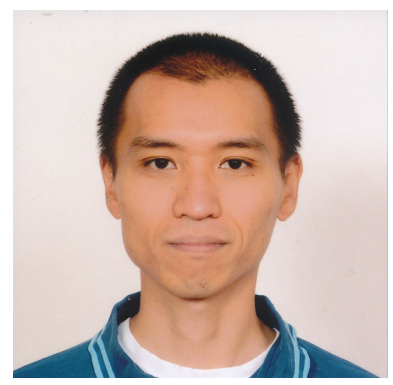

Dr. Chim W. Chan is a postdoctoral researcher at the Department of Microbiology, Tumor and Cell Biology (MTC), Karolinska Institutet, Stockholm, Sweden. His research mainly focuses on malaria parasite and human evolutionary genetics, and health transition in the South Pacific.

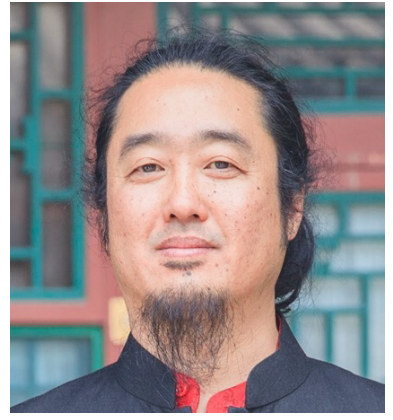

J. Koji Lum is a Professor in the departments of Anthropology and Biological Sciences and Director of the Laboratory of Evolutionary Anthropology and Health of Binghamton University, State University of New York. 